\title{
Correlations between the Structural and Functional Characteristics of Neurons in the Superficial Laminae and the Hamster's Superior Colliculus ${ }^{1}$
}

\author{
RICHARD D. MOONEY, BRADLEY G. KLEIN, AND ROBERT W. RHOADES ${ }^{2}$ \\ Department of Anatomy, University of Medicine and Dentistry of New Jersey, School of Osteopathic Medicine, and Rutgers Medical \\ School, Piscataway, New Jersey 08854
}

\begin{abstract}
Intracellular recording, receptive field mapping, and horseradish peroxidase (HRP) injection techniques were used to determine the structural and functional characteristics of neurons in the superficial laminae (stratum griseum superficiale and stratum opticum) of the hamster's superior colliculus (SC). Fifty-nine neurons (from 38 different hamsters) were successfully characterized, injected with HRP, and recovered. Of these, 8 were marginal cells, 14 had stellate morphology, 10 had narrow, vertically oriented dendritic trees, 12 had wide, vertically oriented dendritic arbors, and 8 were horizontal cells. Seven neurons had somatodendritic morphologies which did not fall into any of these groups. Overall, the distribution of receptive field properties for these cells matched that obtained in previous extracellular recordings from the superficial SC laminae in this species (Chalupa, L. M., and R. W. Rhoades (1977) J. Physiol. (Lond.) 270: 595626; Chalupa, L. M. and R. W. Rhoades (1978) J. Physiol. (Lond.) 274: 571-592). There were significant correlations between receptive field properties and morphology. Sixtyfour percent of the stellate cells and $75 \%$ of the marginal cells were directionally selective. Only $17 \%$ of the other cell types exhibited this response property. In addition, only $36 \%$ of the stellate cells and $25 \%$ of the marginal neurons were discharged by stationary, flashed spots. Eighty-one percent of the other recovered cells gave reliable responses to such stimuli. Stellate and marginal cells could also be differentiated from the other cell types on the basis of speed selectivity. Only $29 \%$ of the stellate and $13 \%$ of the marginal cells responded to stimulus speeds in excess of $20 \% / \mathrm{sec}$. Seventy percent of the other celis were discharged reliably by stimulus speeds $>20 \%$ sec. Neurons with narrow and wide vertically oriented dendritic trees and horizontal cells could not
\end{abstract}

Received January 25, 1985; Revised May 10, 1985;

Accepted May 13, 1985

1 This work was supported in part by National Institutes of Health Grants EY03546, EY04170, and DE06528, National Science Foundation Grant BNS8500142, The University of Medicine and Dentistry of New Jersey Foundation, and a grant from the American Osteopathic Association. B. G. K. was supported by National Research Scientist Award NS07240. Thanks to Ann Marie Szczepanik, Ginny Reicker, and Diane Woerner for excellent technical assistance and to Eleanor Kells and Patti Vendula for typing the manuscript. Thanks also to Dr. James T. Mcllwain for suggestions on an earlier version of this manuscript.

${ }^{2}$ To whom correspondence should be addressed, at Department of Anatomy, UMCNJ School of Osteopathic Medicine, P. O. Box 55, Piscataway, NJ 08854. be distinguished on the basis of the receptive field properties that we analyzed.

The results of numerous Golgi studies (e.g., Sterling, 1971; Valverde, 1973; Langer and Lund, 1974; Tokunaga and Otani, 1976; Labriola and Laemle, 1977; Mathers, 1977) have indicated that there are a number of distinct cell types in the superficial laminae of the mammalian superior colliculus (SC). Electrophysiological experiments concerned with the functional organization of these laminae have indicated further that superficial layer neurons may be subdivided into several categories on the basis of their responses to visual stimuli (see Chalupa, 1984, for a recent review of this literature).

Up to now, there have been only a few attempts to correlate directly the receptive field properties and structural characteristics of SC neurons. Takahashi and his co-workers (Takahashi et al., 1977; Takahashi and Ogawa, 1978; Ogawa and Takahashi, 1981) stained a variety of SC cells in rabbit and cat with procion yellow but did not assess their receptive field characteristics. They did, however, note in rabbit that neurons which responded to optic nerve stimulation with an initial EPSP, one or two spikes, and a longduration IPSP were narrow field vertical cells. Grantyn et al. (1984) have used horseradish peroxidase (HRP) injection techniques to morphologically characterize SC neurons with ascending or interlaminar axonal projections, but their use of an in vitro preparation precluded any assessment of receptive field properties. Only Irvin et al. (1983) have combined receptive ficld analysis and intracellular injection techniques to study SC neurons. They reported that, in the tree shrew, S-R neurons (see Albano et al., 1978) tended to be narrow field vertical cells, whereas diffuse field and poorly responsive cells had much wider dendritic arborizations.

In the present study, we have used receptive field mapping and intracellular HRP injection techniques in the superficial layers of the hamster's SC. Our results demonstrate that marginal and stellate neurons generally, but not invariably, have receptive field characteristics which distinguish them from other morphological cell types in these laminae.

\section{Materials and Methods \\ Experimental animals and surgical preparation. Thirty-eight normal adult ( 3 to 8 months) hamsters provided data included in this study. Each was anesthetized with sodium pentobarbital $(60 \mathrm{mg} / \mathrm{kg}$. i.p., along with $1.5 \mathrm{ml}$ of a $1.5 \%$ solution of atropine sulfate), and the trachea was cannulated and heart rate recording leads were fixed to the chest. The hamster was placed in a stereotaxic headholder which left the visual field free of obstruction, and the skull overlying the posterior portions of both cerebral cortices was drilled away. The dura was slit and reflected and the exposed cortex was covered with a pool of warm mineral oil. The dura overlying the cisterna magna was also removed to improve recording stability. The eyelids were then gently}


retracted, the pupils were dilated with homatropine hydrobromide, and the corneas were protected with repeated applications of mineral oil. All wound edges were infiltrated with a local anesthetic and the animal was then paralyzed with gallamine triethiodide (initial dose $40 \mathrm{mg} / \mathrm{kg}$, i.p.); then artificial respiration (delivered according to the table of Freminet et al., 1972) was initiated. Paralysis and anesthesia were maintained for the duration of the recording experiment with intermittent injections of sodium pentobarbital and gallamine triethiodide.

Visual stimulation and response properties analyzed Visual stimuli were presented in a manner which has been detailed in a number of previous reports (Rhoades, 1980; Rhoades and Chalupa, 1980; Mooney et al., 1984). The receptive field properties that were analyzed in detail wore those which have been shown previously (e.g., Chalupa and Rhoades, 1977; Rhoades and Chalupa, 1977; Stein and Dixon, 1979) to be characteristic of superficial layer SC neurons in the hamster. These were: (1) Responsivity and response sign (i.e., on, off, or on-off) to stationary flashed stimuli. Here, spots of various sizes were centered on the receptive field activating region (Rhoades and Chalupa, 19//) and flashed tor durations ranging between 0.5 and $2 \mathrm{sec}$. Whether or not the cell responded and the sign of response were noted. (2) Speed selectivity: The cutoff velocity for each cell was determined by moving a spot across the field at various speeds and determining the velocity at which the cell would no longer respond. The spot size and the direction of movement were those which were qualitatively judged to yield the maximum number of action potentials from the cell. Trials with different stimulus velocities were randomized and the intertrial interval was sufficient to ensure that habituation (which occurs only rarely for superficial layer SC neurons in hamster-Chalupa and Rhoades, 1977) did not affect responses. (3) Directional selectivity: This was tested by moving an optimally sized spot across the receptive field in at least eight different directions at the speed judged to yield the maximum number of responses from the cell. Each direction was tested at least five times and the order was randomized. For a cell to be considered directionally selective, the average number of spikes evoked by movement in the preferred direction had to be at least 3 times that in the non-preferred direction. (4) Surround suppression: The responses of many superficial layer SC neurons in hamster as well as in other species (again, see Chalupa, 1984, for a review) are reduced by stimuli having dimensions that exceed those of the receptive field activating region (Rhoades and Chalupa 1977; Chalupa and Rhoades, 1978). We tested for such suppression by moving spots, which exceeded the largest dimension of the receptive field by at least $50 \%$, across the field at the speed and in the direction judged to be optimal for the cell. A neuron was judged to exhibit surround suppression if the large stimulus yielded less than $50 \%$ of the number of spikes obtained with an optimally sized spot.

Recording, electrical stimulation, and HRP injection. SC neurons were recorded with micropipettes pulled from Radnotti Microstar capillaries. These were filled with $6 \%$ HRP (Sigma type VI) in $0.05 \mathrm{M}$ Tris and $0.3 \mathrm{M} \mathrm{KCl}$ and were bevelled to tip diameters of 0.5 to $1.0 \mu \mathrm{m}$ and DC resistances of 70 to 120 megohms. Electrodes were placed on the cortical surface with the aid of a dissecting microscope and the cranial defect was then covered with $3 \%$ agar in physiological saline to minimize movement associated with respiration and vascular pulsation. The electrode was coupled to a Eutectics Model 400A preamplifier, the output of which was displayed on a storage oscilloscope, played over an audiomonitor and converted to standard pulses for construction of rasters or histograms

A concentric bipolar stimulating electrode (tip separation, $0.5 \mathrm{~mm}$ ) was positioned in the ipsilateral caudal thalamus, and 0.05- to 2.0-mA shocks (50 $\mu \mathrm{sec}$ duration, isolated from ground) wore delivered as scarch stimuli. Such shocks (see "Results") produced reliable transynaptic activation of almost all superficial SC neurons presumably via stimulation of retinal and cortical axons of passage. This stimulus was used in conjunction with visual stimulation to "search" for SC cells. Response latency to this shock was also used in conjunction with visual response properties to ensure that the same cell was being recorded both betore and atter HRP injection.

All response properties were assessed extracellularly, and the cell was then impaled by advancing the electrode and intermittently passing brief (250 msec) positive ( $1 \mathrm{nA})$ current pulses. impalement of a cell was indicated by: (1) a rapid 20 to $70-\mathrm{mV}$ drop in resting potential, (2) An increase in action potential amplitude, and (3) the ability to inhibit spontaneous firing with hyperpolarizing current $(1 \mathrm{nA})$. If a stable penetration (as indicated by a resting potential of at least $20 \mathrm{mV}$ and no injury discharges) was achieved, the responses of the neuron were quickly reassessed and, if they matched those recorded extracellularly, the cell was injected with HRP by passing 5 . nA positive current pulses ( $250 \mathrm{msec}$ duration) at a rate of $1.6 \mathrm{~Hz}$ for 1 to 5 $\mathrm{min}$. The responses of the cell were usually retested during and, if possible, at the termination of the HRP injection. We attempted no more than three superficial layer injections in a given SC, and these were usually separated by at least $800 \mu \mathrm{m}$.

Perfusion, tissue processing, and reconstruction of HRP-filled neurons. No more than $8 \mathrm{hr}$ after the first attempted injection, hamsters were injected intraperitoneally with 1000 units of heparin and $50 \mathrm{mg}$ of sodium pentobarbital and were perfused transcardially with $250 \mathrm{ml}$ of a prewash that contained 5000 units of heparin, $10 \mathrm{mg}$ of xylocaine, and $2.25 \mathrm{gm}$ of $\mathrm{NaCl}$ in $0.1 \mathrm{M}$ sodium phosphate buffer $\left(\mathrm{pH} 7.3,21^{\circ} \mathrm{C}\right)$. This was followed by $500 \mathrm{ml}$ of a fixative which consisted of $1 \%$ paraformaldehyde, $25 \%$ glutaraldehyde, and $4 \%$ sucrose in $0.1 \mathrm{M}$ sodium phosphate buffer $\left(\mathrm{pH}=7.3,4^{\circ} \mathrm{C}\right)$. Following the perfusion, the head was removed and stored in a $10 \%$ buffered sucrose solution $\left(4^{\circ} \mathrm{C}\right)$ for 12 to $60 \mathrm{hr}$. Brains were then removed and a block containing the diencephalon and midbrain was cut transversely $(100 \mu \mathrm{m}$ sections) on a freezing microtome. Sections were collected in $0.1 \mathrm{M}$ sodium phosphrate buffer ( $\mathrm{pH} \mathrm{7.3)}$ and reacted by a recent modification of Adams (1977) cobalt-intensified diaminobenzidine reaction (see Semba et al., 1983, for details). To minimize tissue shrinkage, sections were then soaked for approximately $2 \mathrm{~min}$ in a $2 \%$ gelatin solution (sodium phosphate buffered $\mathrm{pH}$ 7.3) and mounted onto gelatinized slides. Tissue was air-dried, dehydrated for $30 \mathrm{~min}$ in absolute ethanol, cleared in xylene, and coverslipped.

Cells were reconstructed from serial sections at a total magnification of $\times 720$ using a microscope equipped with a $\times 40$ planapochromatic objective and a drawing tube. Soma sizes were determined from drawings made at a total magnification of $\times 1600$ using a $\times 100$ oil immersion objective. Soma areas were measured with the aid of a graphics tablet interfaced to an Apple $\|+$ computer.

Laminar boundaries in the colliculus were determined in most cases by simply examining sections using darkfield optics. This permits excellent visualization of the alternating cellular and fibrous laminae which comprise the SC. In a number of brains, laminar boundaries determined in this manner were cross-checked by removing the coverslips after the cells were photographed and drawn, and counterstaining the sections with thionin.

\section{Results}

The 38 hamsters in which successful experiments were carried out provided a total of 59 well filled cells in the stratum griseum superficiale (SGS) and stratum opticum (SO). The maximum number of neurons recovered from a given animal was four; this occurred in two hamsters. Three hamsters contributed three cells to the sample and no other animal provided more than two. We grouped these neurons into five categories based on their somatodendritic morphology: marginal cells, stellate cells, neurons with relatively narrow $(<300 \mu \mathrm{m})$, vertically oriented dendritic arbors, cells with widespread (>300 $\mu \mathrm{m}$, but usually in excess of $700 \mu \mathrm{m}$ ) vertically oriented dendritic arbors, and horizontal cells. Figure 1 shows the approximate locations of the somata of these neurons in four SC sections stained for fibers by the Gallyas (1979) technique. As can be seen, all except the most caudomedial portion of the superficial laminae was sampled. This region is covered by the sinus confluens which could not be penetrated by our micropipettes. Overall, 38 of the recovered neurons had their somata in the SGS and the remainder were in the SO.

The receptive field properties of the recovered neurons (Table I) matched, fairly closely, the distributions for larger samples obtained in previous extracellular recording experiments (e.g., Chalupa and Rhoades, 1977; Rhoades and Chalupa, 1978). Ninety percent ( $N=$ 53 ) of the cells were exclusively visual; the remainder were either unresponsive $(N=3)$ or somatosensory $(N=3)$. Of the visual cells, $39 \%$ were directionally selective and the majority (68\%) preferred movement with an upward component. Half of the cells responded only to stimulus velocities $<10 \% / \mathrm{sec}$ and most $(60 \%)$ were discharged reliably by stationary, flashed stimuli. Finally, $55 \%$ of the recovered visual cells had their responses attenuated by stimuli larger than the receptive field activating region. The data presented in the following sections demonstrate that these receptive field properties were not uniformly distributed across morphologically defined cell types.

Marginal cells. We characterized and recovered eight marginal colls. Four of these cells are illustrated in Figures 2 to 4 . These neurons had small (mean soma area $=77.8 \mu \mathrm{m}^{2}, \mathrm{SD}=15.9$ ) cell 

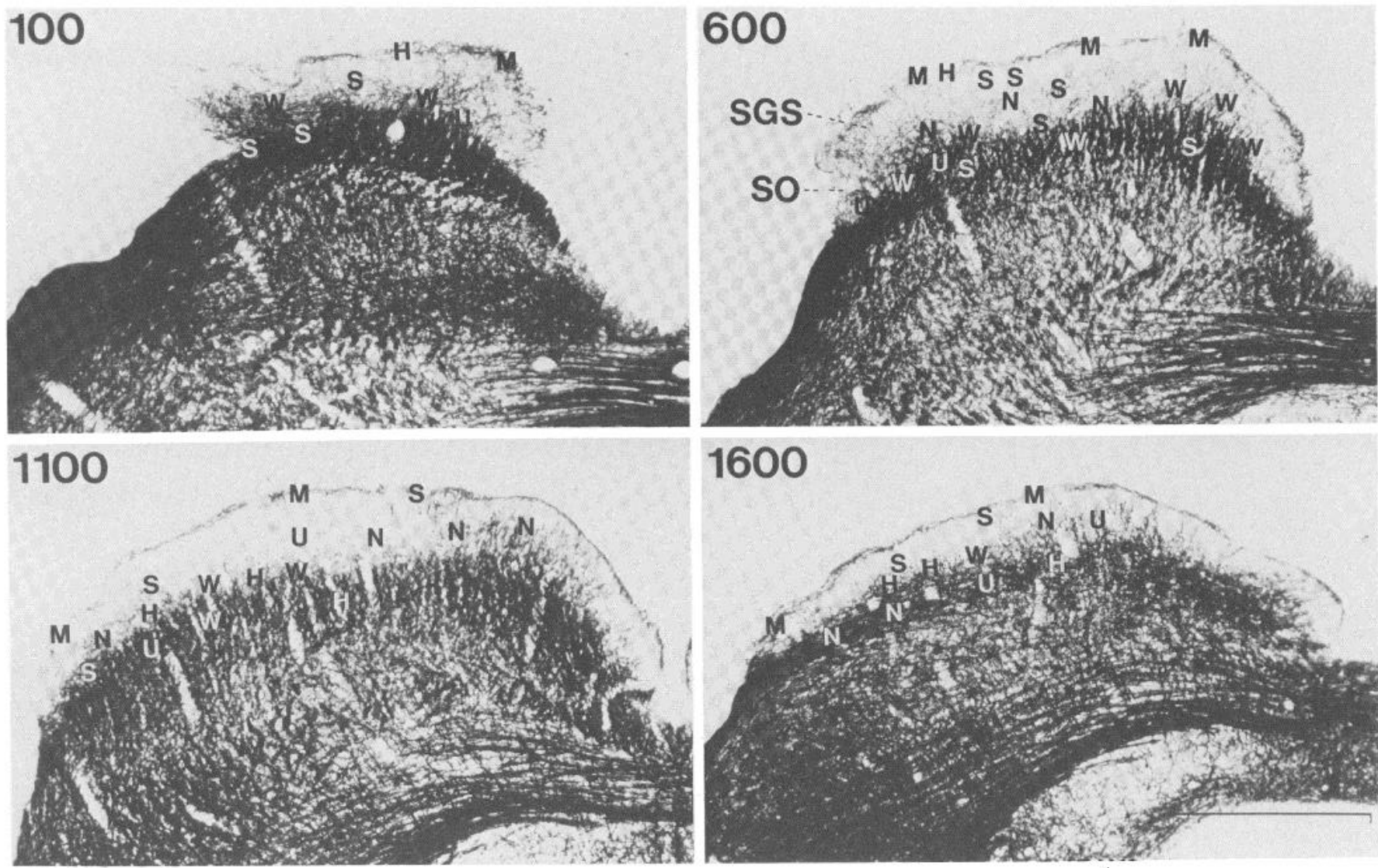

Figure 1. Coronal sections stained using the Gallyas (1979) method showing the approximate locations of superficial layer cells recovered in this study. $M$, marginal cell; $S$, stellate cells; $N$, neurons with narrow vertically oriented dendritic trees; $W$, cells with widespread vertically oriented dendritic arbors; $H$, horizontal cells; $U$, cells which could not be placed into any of these groups. The numbers in the upper lefthand corner of each photomicrograph denote the distance between each section and the rostral border of the tectum. The calibration marker is $500 \mu \mathrm{m}$.

TABLE I

Response property summary for the 59 superficial layer cells characterized and recovered in this study

The response properties studied were: spontaneously active (Spont. Act.), directionally selective (Dir. Sel.), velocity selective (Vel. Sel.), responsive to a flashed standing spot (Resp. STSP), and suppressed by a spot larger than the receptive field activating region (Supp.). Note that only four of five visually responsive cells that could not be morphologically classified were tested for directional selectivity, three were tested for speed selectivity, and four were tested for response suppression by large stimuli.

\begin{tabular}{|c|c|c|c|c|c|c|c|}
\hline \multirow{2}{*}{ Cell Type } & \multirow{2}{*}{$(N)$} & \multirow{2}{*}{$\%$ Visual } & \multirow{2}{*}{$\%$ Spont. Act. } & \multicolumn{4}{|c|}{ Visual Responses } \\
\hline & & & & \% Dir. Sel. & \% Vel. Sel. & \% Resp. STSP & $\%$ Supp. \\
\hline Marginal & $(8)$ & 100 & 0 & 75 & 88 & 25 & 60 \\
\hline Stellate & (14) & 100 & 14 & 64 & 71 & 36 & 60 \\
\hline Wide Vertical & (12) & 75 & 50 & 33 & 22 & 88 & 67 \\
\hline Horizontal & $(8)$ & 88 & 43 & 0 & 29 & 100 & 57 \\
\hline Unclassified & (7) & 71 & 80 & 25 & 33 & 60 & 50 \\
\hline
\end{tabular}

bodies which were located at or just below the tectal surface. Their dendrites generally descended into the SGS and upper SO. Their dendritic fields were usually quite limited and did not extend more than $150 \mu \mathrm{m}$ in either the mediolateral or rostrocaudal planes. The one exception to this generalization is the neuron illustrated in Figures 3 and 4 . This cell's dendrites extended over $300 \mu \mathrm{m}$ mediolaterally. Four of the marginal cells we recovered were stained well enough to permit reconstruction of their axonal arborizations. Two of these are shown in Figures 3 and $4, A$ and $C$. In both instances, most of the axonal arbor was restricted to the region of the cell's dendrites. However, both cells also sent collaterals into the SO and the deep laminae. A more detailed description of the axonal projections of superficial layer cells into the deep laminae will be provided in a separate communication (R. D. Mooney, B. G. Klein, and R. W. Rhoades, manuscript in preparation).

As a group, the marginal cells were physiologically quite homogeneous (see Table I). All were visual, none were spontaneously active, and only $25 \%(N=2)$ responded to stationary, flashed stimuli. Seventy-five percent $(N=6)$ were directionally selective, and all but one of these preferred movement with an upward component. All but one of the marginal cells responded only to low speeds and $60 \%$ ( 3 of the 5 tested) exhibited surround suppression. 


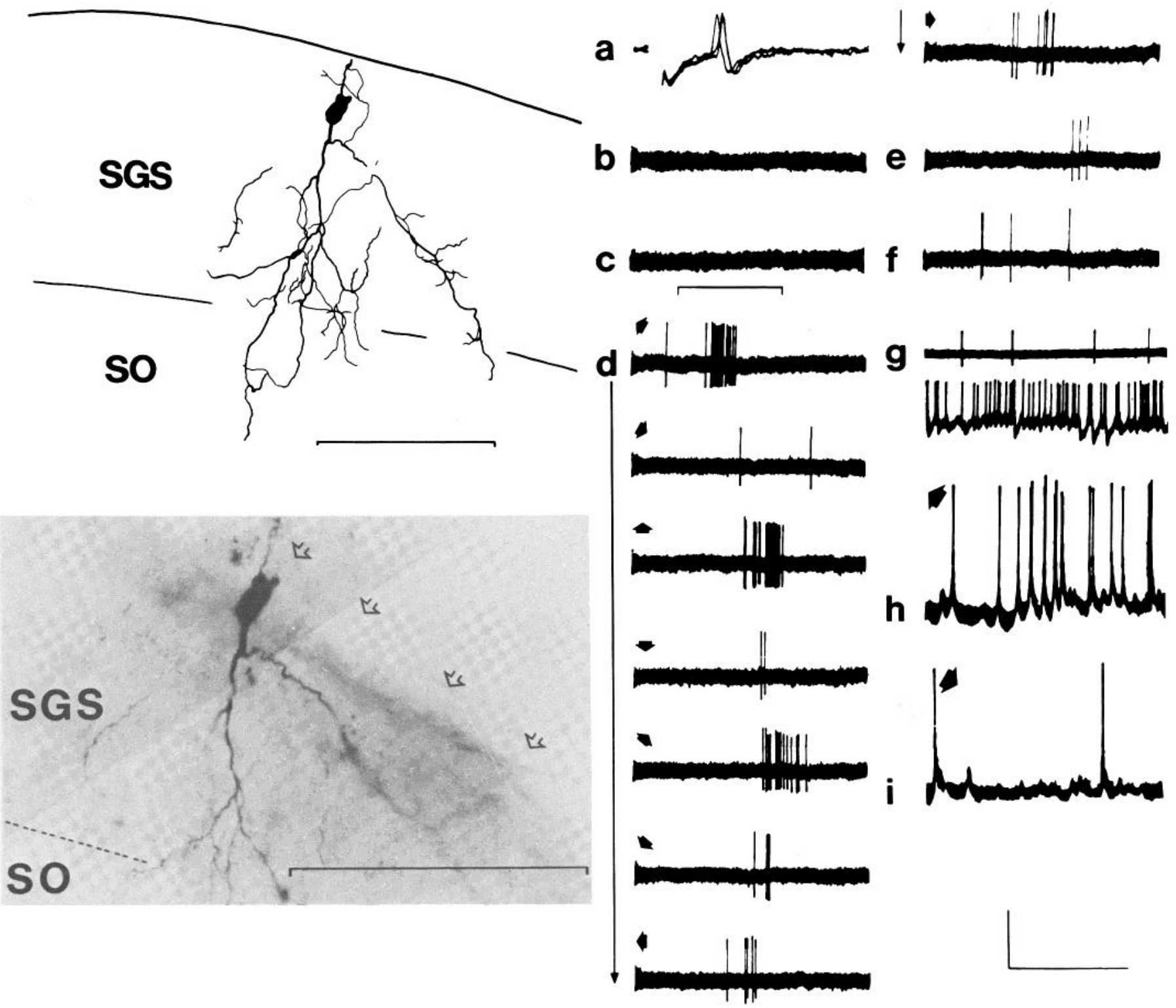

Figure 2. Photomicrograph, reconstruction, and oscillographs illustrating the responses of a marginal cell. The dendrites of the cell descended through the SGS and terminated in the SO. They were almost entirely free of spines. The cell's axon arose from the dorsal part of the soma but could not be traced. The calibrations in the reconstruction and photomicrograph are $100 \mu \mathrm{m}$. The series of small open arrows denote the surface of the SC in this and all subsequent figures. a (three overlapped oscilloscope traces) shows the cell's response to thalamic shocks (125 $\mu \mathrm{A}), b$ demonstrates that the neuron had no spontaneous activity, and $c$ shows the lack of response to a flashed spot $\left(1.5^{\circ}\right.$; duration indicated by the bar beneath the oscillograph). The traces in $d$ demonstrate that the cell had a strong preference for upward movement $\left(1.5^{\circ}\right.$ spot, speed $=8^{\circ} / \mathrm{sec}$, receptive field size $=2^{\circ} \times 4^{\circ}$; arrows indicate directions of stimulus movement). $e$ shows the reduction in the response when a large spot was used for stimulation, and $f$ illustrates the reduced discharge elicited by a $1.5^{\circ}$ spot moved at $20^{\circ} / \mathrm{sec}$. g shows two traces obtained immediately before and after the penetration of the cell. Initially, the DC shift was only 15 $\mathrm{mV}$ and the spike height was small. As the penetration stabilized, the resting potential became $25 \mathrm{mV}$ and the action potentials increased in amplitude. The traces in $h$ and $i$ illustrate the same directional selectivity shown by the extracellular traces. Stimulus conditions are the same as in $d$ and arrows denote directions of stimulus movement. The calibrations are $5 \mathrm{mV}$ and $5 \mathrm{msec}$ for $a, 5 \mathrm{mV}$ and $2.5 \mathrm{sec}$ for $b$ to $f$, and $10 \mathrm{mV}$ and $2.5 \mathrm{sec}$ for $g$ to $i$.

Oscilloscope traces depicting responses typical of cells from this class are provided in Figure 2.

Stellate cells. Fourteen of the neurons recovered had stellate morphology. The somata (mean area $=82.2 \mu \mathrm{m}^{2}, \mathrm{SD}=15.9$ ) of these cells were scattered throughout the SGS $(N=9)$ and SO $(N$ $=5$ ). Cells typical of those included in this group are illustrated in Figures 5 to 7 . Most had limited dendritic arborizations which extended no more than $200 \mu \mathrm{m}$ away from the cell body. The dendrites of these cells were often, but not invariably, covered with spines (e.g., Figs. 6 and 7, C and D). The axonal arborizations of these cells were usually restricted to the region of the neuron's dendritic tree (e.g., Fig. 7D); however, several stellate cells in the SGS sent a few collaterals into the uppermost part of the SO (Figs. 5 and $7 A$ ).

The distribution of receptive field properties for the recovered stellate neurons was very similar to that for the marginal neurons (Table I). All were exclusively visual; only $14 \%$ were spontaneously active and most (64\%) did not respond to stationary flashed stimuli. Sixty-four percent of the stellate cells were directionally selective and most $(56 \%)$ of these again preferred movement with an upward component. Seventy-one percent of these cells responded only to low stimulus velocities and most $(60 \%)$ had their responses suppressed by stimuli which extended beyond the receptive field acti- 

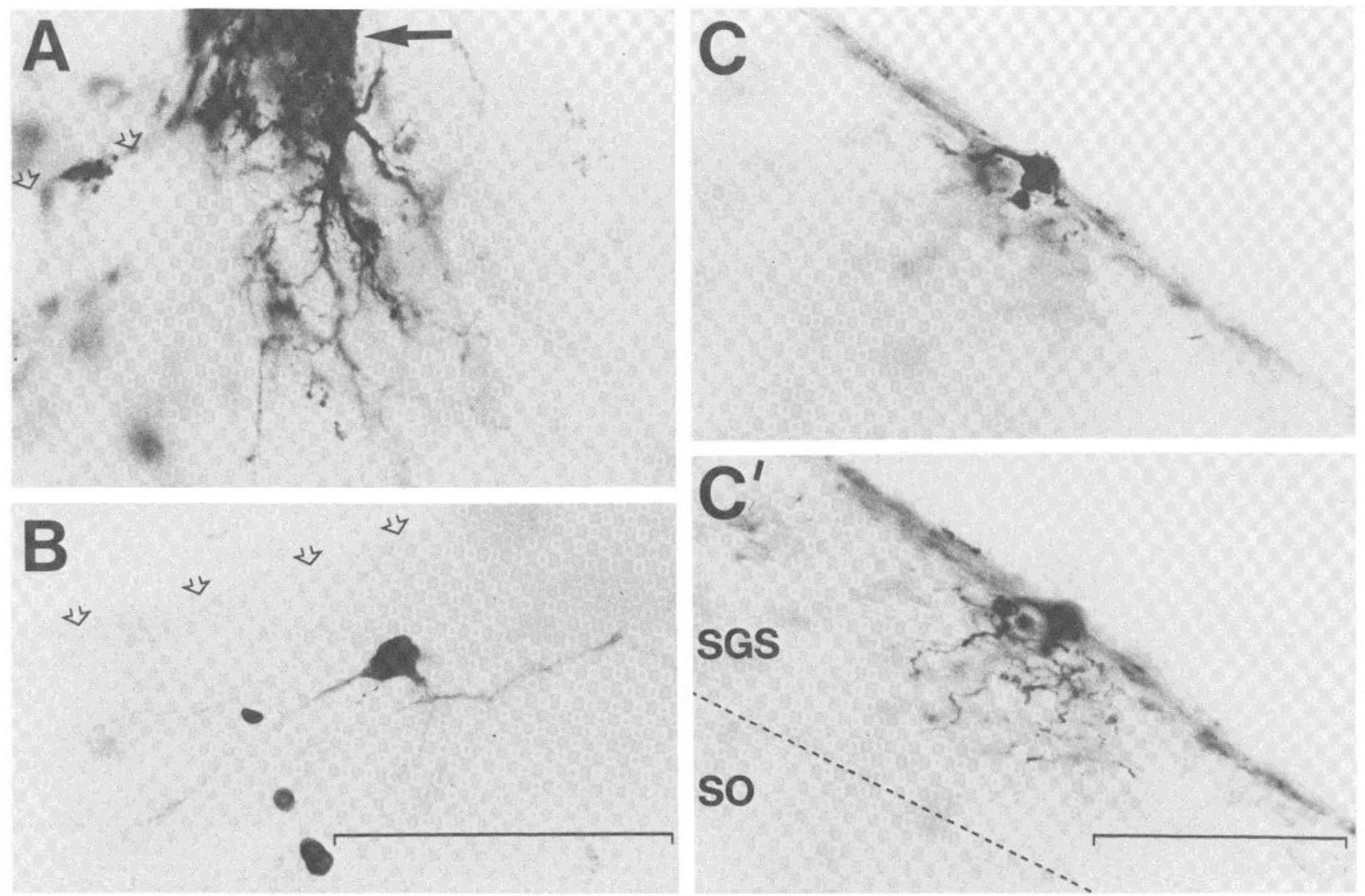

Figure 3. Photomicrographs of three additional marginal cells which are reconstructed in Figure 4. Conventions are the same as in Figure 2. The dark mass denoted by the solid arrow in $A$ is pia which adhered to the SC surface. $C$ and $C^{\prime}$ are photomicrographs of the same cell taken at different focal planes. $C$ shows the soma and $C^{\prime}$ the neuron's proximal dendrites. The calibrations are all $100 \mu \mathrm{m}$; that in $B$ also applies to $A$.

vating region. Figure 5 shows oscilloscope traces from a typical stellate cell, and it also serves to illustrate the manner in which the salient response characteristics of a given neuron were tested before and after impalement. The traces in Figure $5, a$ and $b$, are extracellular, and they show that this neuron responsed at a relatively long ( $7.5 \mathrm{msec}$ ) latency to posterior thalamic shocks (Fig. $5 \mathrm{a}$ ) and that it had a strong preference for stimuli moving in the upper temporal direction (Fig. 5b). The traces in Figure 5, $c$ and $d$, are intracellular, and they were obtained after HRP had been iontophoresed into the cell for $3 \mathrm{~min}$. They show the same response latency to posterior thalamic shocks (Fig. $5 \mathrm{c}$ ) and the strong preference for upper temporal stimulus movement (Fig. $5 d$ ).

Neurons with narrow, vertically oriented dendritic arbors. We recovered 10 cells with narrow $(<300 \mu \mathrm{m})$, vertically oriented dendritic trees. Five cells which illustrate the range of morphological variability for this class are shown in Figures 8 to 10 . These cells were larger than either the marginal or stellate cells (mean soma area $\left.=95.5 \mu \mathrm{m}^{2}, \mathrm{SD}=28.2\right)$, and most $(80 \%, N=8)$ had somata located in the lower one-half of the SGS (e.g., Fig. 10, $A$ to $C$ ). The two remaining neurons in this class had their cell bodies in the SO (Figs. 8, 9, and 10D). The dendrites of these neurons usually arose from the dorsal aspect of the cell body and then arborized extensively. In most instances they were fairly covered with spines.

The axonal arborizations of the neurons in this class were extremely variable. Five had axons which did not extend far beyond the neuron's dendritic tree (e.g., Fig. 10C), two had more extensive collaterals which remained in the same lamina as the cell body (e.g., Fig. 10D), and three had axon arbors which extended out of the superficial layers and arborized fairly extensively in the underlying stratum griseum intermediale (SGI) (Figs. 8 and $10, A$ and $B$ ).

The narrow field vertical cells were quite different functionally from the marginal and stellate neurons. All were exclusively visual, $40 \%$ were spontaneously active, and most (70\%) were discharged by flashed stimuli. Only one of these cells ( $10 \%$ of the sample) was directionally selective and it preferred upward movement. Most $(60 \%)$ of the narrow field vertical cells responded equally well to a wide range of stimulus velocities, and $44 \%$ exhibited surround suppression. Oscilloscope traces which illustrate the response of a narrow field vertical cell are provided in Figure 8.

Neurons with wide, vertically oriented dendritic arborizations. We recovered 12 cells with wide, vertically oriented dendritic trees. Four of these are illustrated in Figures 11 to 13. These neurons were located in either the lowermost SGS $(N=8)$ or the SO $(N=4)$. They had the largest cell bodies (mean soma area $=141.8 \mu \mathrm{m}^{2}$, SD $=33.4$ ) of any of the superficial layer neurons that we recovered. They had very broad dendentric trees which extended for up to 900 $\mu \mathrm{m}$ in the mediolateral plane (e.g., Fig. $13, A$ and $B$ ). Regardless of the laminar location of the soma, the dendrites of cells in this class always extended into the uppermost part of the SGS, usually reaching the pial surface (e.g. Figs. 12 and 13, A to C). The dendrites of cells in this class were usually covered with spines.

In those instances where the axonal arborization of a wide field vertical cell could be traced, it usually collateralized most extensively ventral to the soma (Figs. 11 and $13, B$ and $C$ ). Six of the eight wide field vertical cells with axons that could be traced had numerous collaterals in the SGl (e.g., Fig. 13, B and C). 

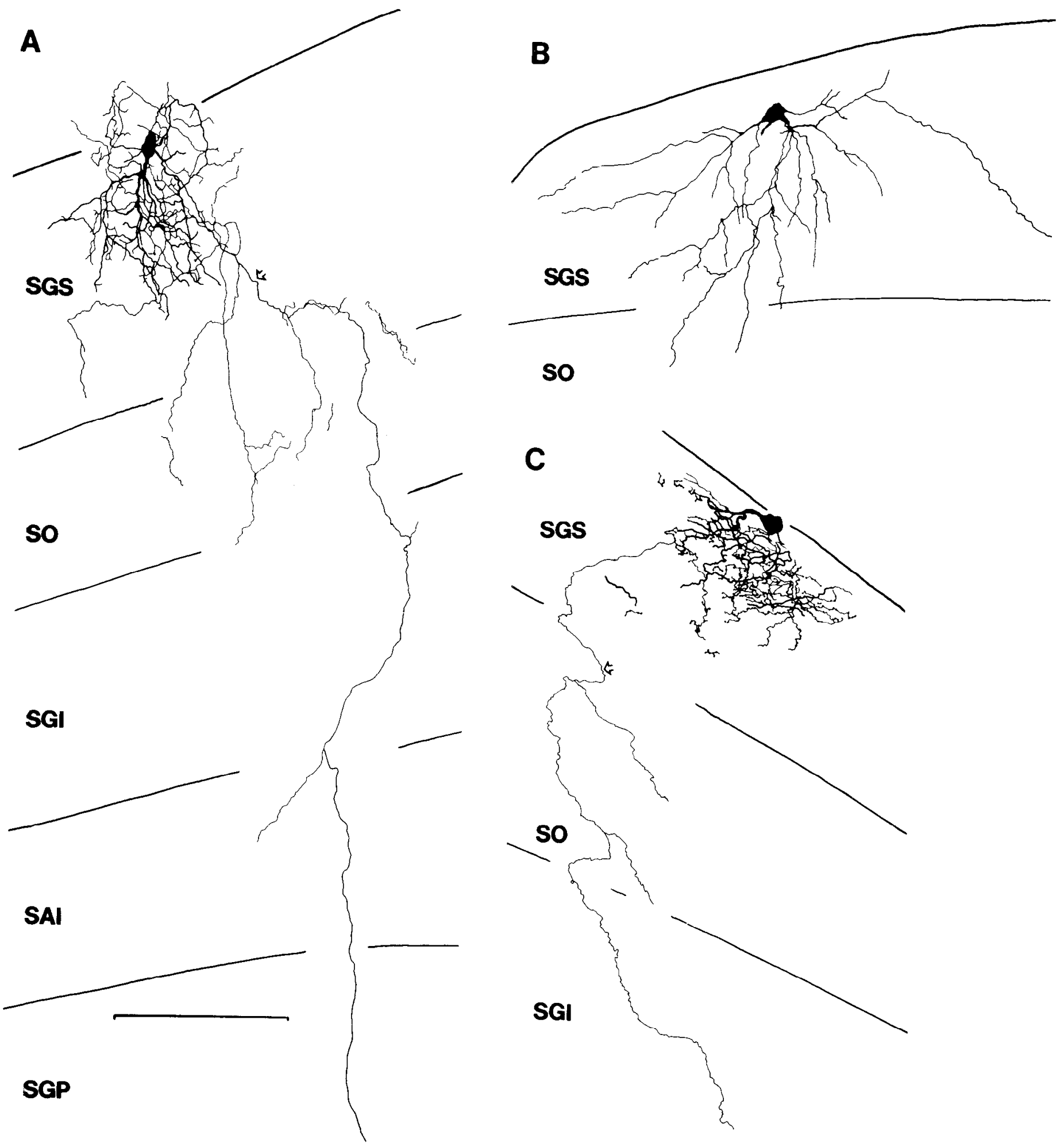

Figure 4. Reconstructions of the marginal cells illustrated in Figure 3. The cell in A had a dense dendritic arbor which was restricted to the SGS. Its axon (open arrow) was well filled and gave off collaterals in the SGS and SO. It could he traced as far as stratum griseum profundum (SGP). The cell in $B$ had fairly widespread, ventrally directed dendrites restricted almost completely to the SGS. Its axon could not be traced. The cell in C had a small dendritic arbor restricted to the SGS. Most of the cell's axonal collateralization was restricted to the region of the dendritic field, but one process could be traced as far as the SGl. All threc of thesc neurons were directionally selective and responded only to slowly moving stimuli. None were discharged by flashed spots. SAI, stratum album intermedium Calibration bar, $100 \mu \mathrm{m}$.

Nine of the 12 wide field vertical neurons were visual, one was somatosensory and two were unresponsive. Of the visual cells, $33 \%$ were direclionally selective, $78 \%$ responded to a wide range of stimulus velocities, $88 \%$ were reliably discharged by flashed spots, and $67 \%$ had their responses suppressed by stimuli larger than the receptive field activating region. Fifty percent of the wide field vertical cells were spontaneously active. Traces illustrating the responses typical of those from cells in this class are provided in Figure 11. 


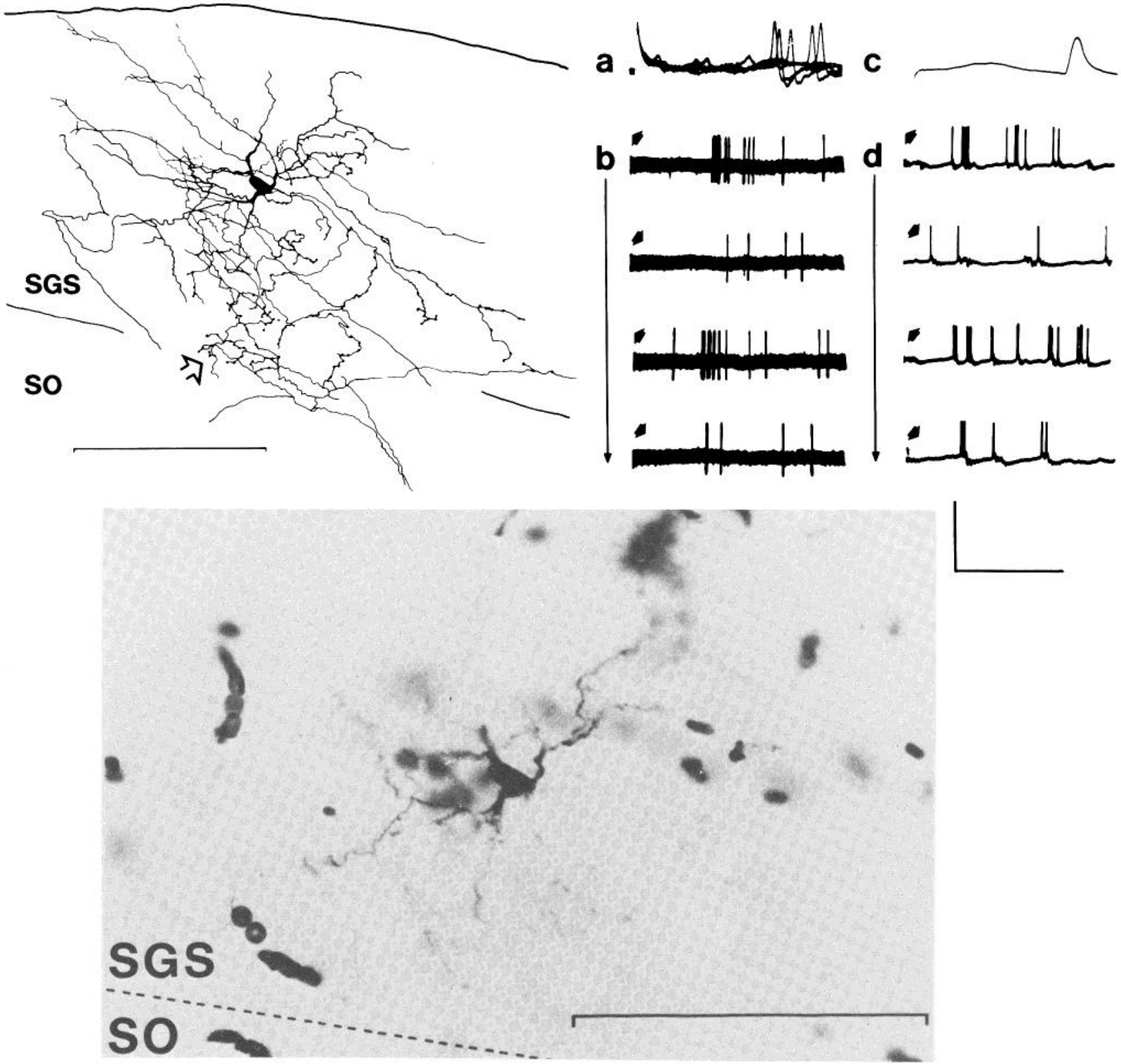

Figure 5. Photomicrograph, reconstruction, and oscillographs illustrating the responses of a stellate neuron. The cell's soma was located in the middle of the SGS and its dendrites, which were almost completely free of spines, were restricted to this layer. The cell's axon gave off numerous en passant and terminal boutons and it was also restricted to the SGS near the region of the neuron's dendritic tree. The calibrations are $100 \mu \mathrm{m}$. The traces shown in a illustrate the relatively long $(8.5 \mathrm{msec})$ response to thalamic shocks $(280 \mu \mathrm{A})$ and those in b demonstrate the neuron's directional selectivity. $c$ and $d$ illustrate similar responses obtained after the cell was impaled. The calibrations are $5 \mathrm{mV}$ and $5 \mathrm{msec}$ for $a, 5 \mathrm{mV}$ and $5 \mathrm{sec}$ for $b, 50 \mathrm{mV}$ and $5 \mathrm{msec}$ for $c$, and 50 $\mathrm{mV}$ and $5 \mathrm{sec}$ for $d$.

Horizontal cells. We characterized and recovered eight horizontal cells. Five of these are illustrated in Figures 14 to 16 . The somas of these neurons were located either just below the collicular surface $(N=2$; e.g., Fig. 16D) or at the border between the SGS and the SO $(N=6$; Figs. 14 and $16, A$ to $C)$. The average soma area for cells in this class was $111.3 \mu \mathrm{m}^{2}(\mathrm{SD}=43.4)$, and their distinguishing feature was extremely widespread dendritic arbors which extended both dorsally and ventrally from the level of the cell body. The cell shown in Figure $16 \mathrm{C}$ had dendrites which spanned almost $1400 \mu \mathrm{m}$ in the mediolateral plane.

Only one of the horizontal cells we recovered (shown in Figs. 15 and $16 B$ ) had a process that could be unequivocally identified as an axon. It had a limited collateralization in the SGS.
Seven of the eight $(88 \%)$ recovered horizontal neurons were exclusively visual. The remaining cell in this class was unresponsive. Forty-three percent were spontaneously active. None of the visual cells were directionally selective, $29 \%$ were velocity selective, all responded to flashed spots, and $57 \%$ had their responses suppressed by stimuli larger than the activating region of the receptive field.

Unclassifiable cells. We recovered seven superficial layer neurons which could not be placed in the five categories described above. Three of these cells are illustrated in Figures 17 and 18. Functionally, these neurons were fairly heterogeneous. Five were visual, one was somatosensory, and one was unresponsive. One of the visual cells was directionally selective, one was speed selective, three were 

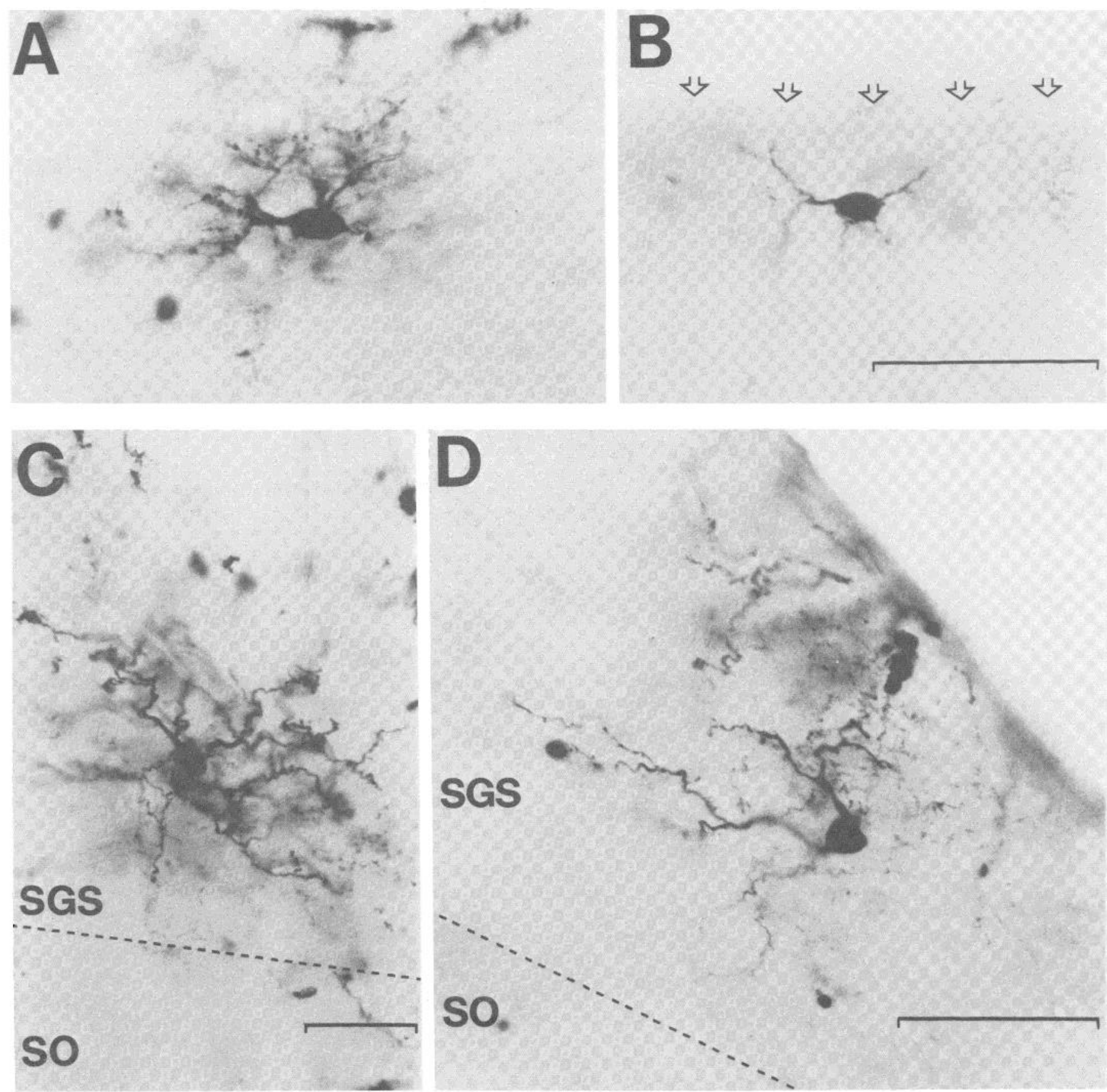

Figure 6. Photomicrographs of four additional recovered stellate cells. These neurons are reconstructed in Figure 7. The calibrations are all $50 \mu \mathrm{m}$ and that in $B$ also applies to $A$. All conventions are the same as in Figure 2.

responsive to flashed stimuli and one had its responses suppressed by stimuli larger than the receptive field activating region.

Correlations between structure and function. The data presented in the preceding sections and Table I indicate that a given constellation of receptive field properties was not invariably associated with a given morphological class. There were, however, several statistically reliable relationships between structure and function for superficial layer SC neurons. The most clearcut functional differences between morphologically defined types were between marginal and stellate cells and the neurons in the other structural categories. Marginal and stellate cells were in most cases directionally selective, whereas neurons in the other groups were not $\left(\chi^{2}=16.7, d f=5\right.$, $p<0.01$ ). With two exceptions, marginal and stellate cells were not spontaneously active. More than $50 \%$ of the other cell types we recorded had measurable spontaneous activity $\left(\chi^{2}=12.5, d f=5\right.$, $p<0.05$ ). Most marginal and stellate neurons did not respond to flashed stimuli. More than $75 \%$ of the cells in the other classes were discharged by flashed spots $\left(\chi^{2}=15.8, d f=5, p<0.01\right)$. Finally, more than $75 \%$ of the marginal and stellate neurons responded only to stimulus velocities $<20^{\circ} / \mathrm{sec}$. Greater than three-fourths of the other cell types responded to a much wider range of stimulus speeds $\left(\chi^{2}=12.5, d f=5, p<0.05\right)$.

\section{Discussion}

The data presented in the preceding section demonstrate that there are statistically reliable correlations between the structural and functional characteristics of visual neurons in the superficial layers 


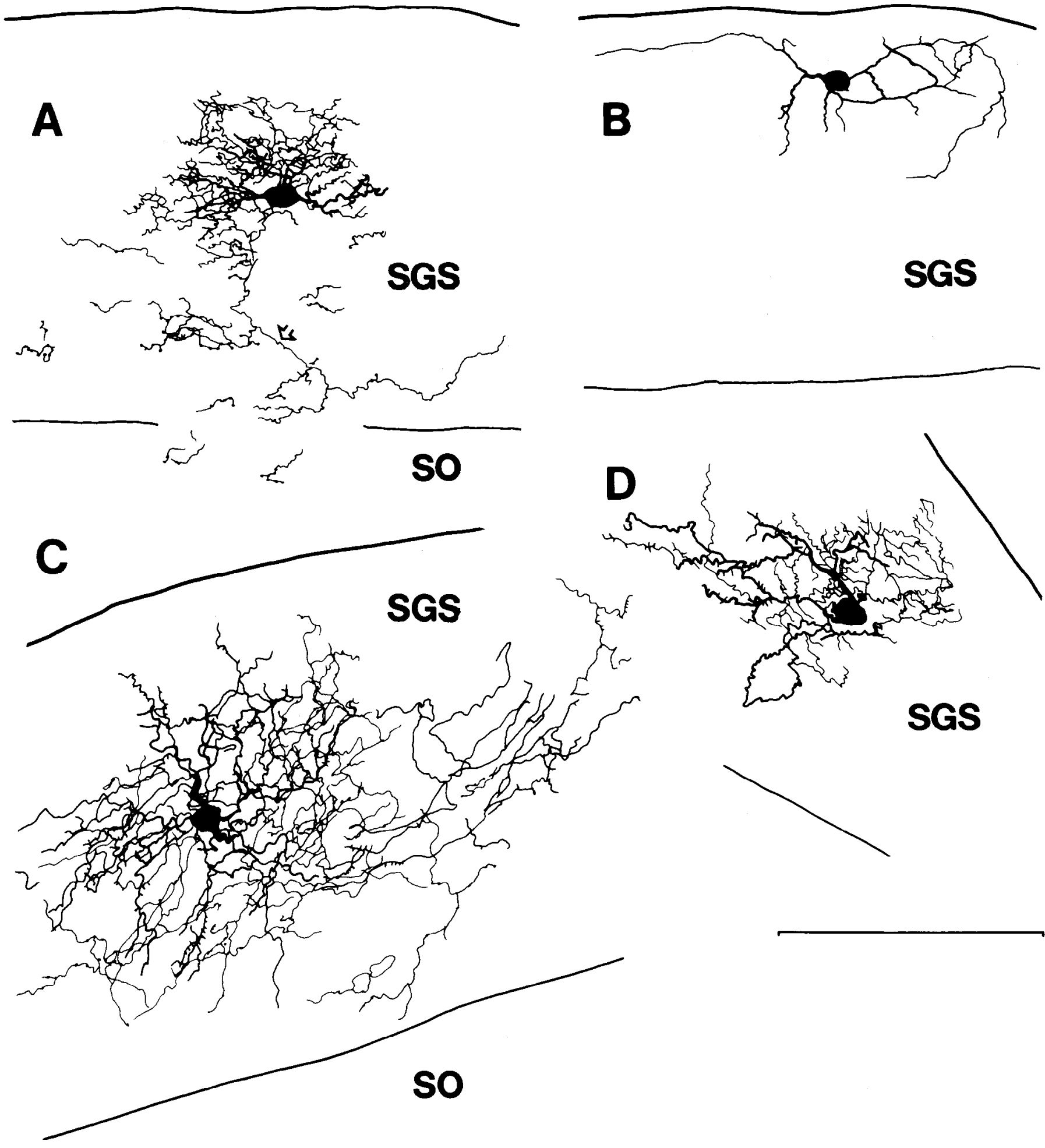

Figure 7. Reconstructions of the four stellate cells shown in Figure 6 . The cell in $A$ had a very small dendritic arborization that was restricted to the middle part of the SGS. Its axonal collateralization (the axon is denoted by the open arrow) was primarily in the lower SGS and SO. The soma and dendrites of the cell in $B$ were in the upper one-third of the SGS. Its axon could not be traced. The cell in $C$ had its soma in the middle of the SGS, and both its dendritic and axonal arborizations were restricted to this lamina. The stellate cell in $D$ was also in the middle of the SGS. The calibration is $100 \mu \mathrm{m}$. The neurons illustrated in $A, B$, and $D$ were all directionally selective and responded only to slowly moving stimuli. None were discharged by flashed spots. The cell in $C$ was not directionally selective, but its other receptive field properties were similar to those of the other stellate neurons shown.

of the hamster's SC. Neurons with either marginal or stellate morphology tend to be movement sensitive, directionally selective, and to respond only to low stimulus velocities. Narrow field vertical, wide field vertical, and horizontal cells, in contrast, usually give reliable responses to flashed stimuli and respond to all directions of movement and also to a wide range of stimulus velocities.

In discussing these findings, there are at least three issues which should be considered: (1) How do our structural and functional data 


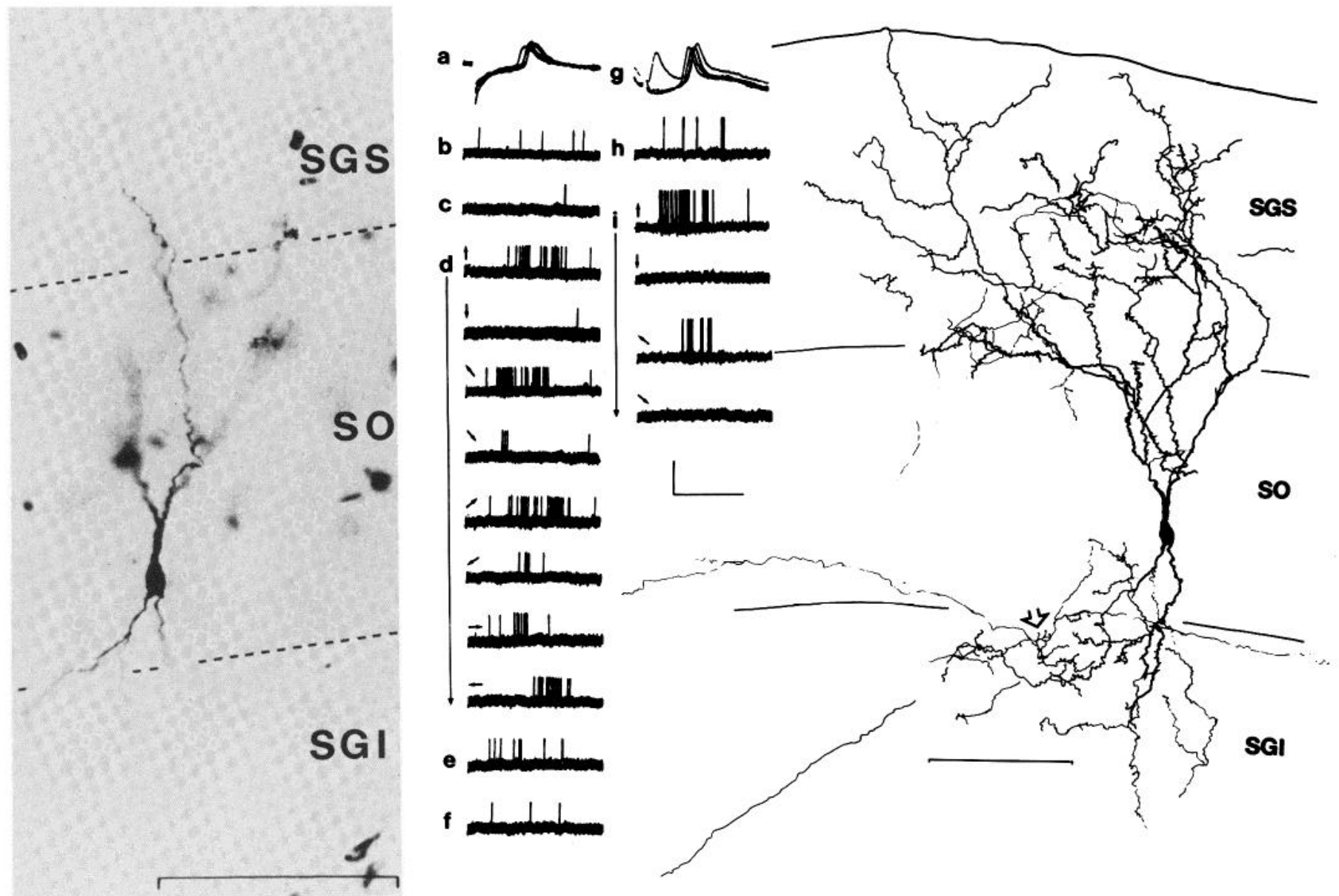

Figure 8. Photomicrograph, reconstruction, and oscillographs illustrating the responses of a cell with narrow, vertically oriented dendritic arbors. The soma of this neuron was located in the SO. It gave off two dorsally directed dendrites which branched extensively in the SO and SGS. Both the proximal and distal dendrites had numerous spines. The cell also gave rise to a single ventrally directed dendrite which terminated in the SGI. The axon is this cell (right, open arrow) ramified, for the most part, in the lowermost SO and upper SGl. The calibrations are $100 \mu \mathrm{m}$. The five overlapped traces in a show the response to thalamic shock $(260 \mu \mathrm{A}), b$ illustrates the cell's spontaneous activity, and $c$ shows the lack of response to a flashed stimulus. $d$ shows the directionally selective responses to a moving stimulus. Note the lack of response to movement with a downward component. $e$ and $f$ show the attenuation of the neuron's response when speeds of 25 and $50 \% \mathrm{sec}$ were used. In both traces, the direction of movement is up. $g$ illustrates the cell's response to thalamic shocks after it was impaled. $h$ illustrates spontaneous activity and $i$ the cell's directionally selective response to a moving spot. The calibrations are $5 \mathrm{mV}$ and $5 \mathrm{msec}$ for $a, 5 \mathrm{mV}$ and $2.5 \mathrm{sec}$ for $b$ to $f, 20 \mathrm{mV}$ and $5 \mathrm{msec}$ for $g$, and $20 \mathrm{mV}$ and $2.5 \mathrm{sec}$ for $h$ and $i$.

fit with the results of similar studies in other species? (2) To what extent do the structural types we have defined on the basis of intracellular HRP injections correspond to the morphological categories developed in previous Golgi studies? (3) How well do our findings with regard to the responses of specific cell types in defined SC laminae fit with what is known regarding the visual afferents to these layers and their roles in the development of visual receptive field properties?

Relationship to previous structure-function studies of the superficial SC laminae. As noted at the beginning of this paper, only a single study (Irvin et al., 1983) has attempted to correlate the receptive field properties and morphology of individual SC neurons. Our data with respect to narrow field vertical cells appear to coincide well with those which Irvin et al. (1983) reported for such neurons in the tree shrew. In both species, these neurons give reliable (generally on-off) responses to flashed stimuli and are insensitive to the direction of stimulus movement. Our findings for neurons with wider dendritic arbors do not, however, appear to agree with those reported by Irvin et al. (1983). They described such cells as being either diffusely visual or poorly responsive. In hamster the response characteristics of narrow and wide field vertical cells were actually quite similar.
Our data for horizontal cells substantiate previous observations (Takahashi and Ogawa, 1978; Ogawa and Takahashi, 1981) that such neurons are capable of supporting action potentials. Although previous Golgi studies (e.g., Langer and Lund, 1974) showed that such cells do give rise to axons, it was suggested that they might not have action potentials. All of the horizontal cells we recovered did yield action potentials.

Structural categories for collicular neurons. In general, the morphological categories we defined on the basis of our small sample of HRP-injected cells coincide fairly well with those established in previous Golgi experiments. The neurons we classed as marginal cells are very similar to those illustrated for the rat by Langer and Lund (1974) and Labriola and Laemle (1977). Close correspondence with Golgi-stained cells was also the case for the stellate and horizontal cells which we recovered. The major point of difference between our categories and those developed on the basis of Golgi material concerns neurons with vertically oriented dendritic arbors. We have defined two classes - narrow and wide field cells-which are distinguished primarily by the breadth of their dendritic arbors (see "Results"). The Golgi literature for rodent SC (Langer and Lund, 1974; Labriola and Laemle, 1977; but also see Tokunaga and Otani, 1976) has generally delineated three types of neurons with vertically 


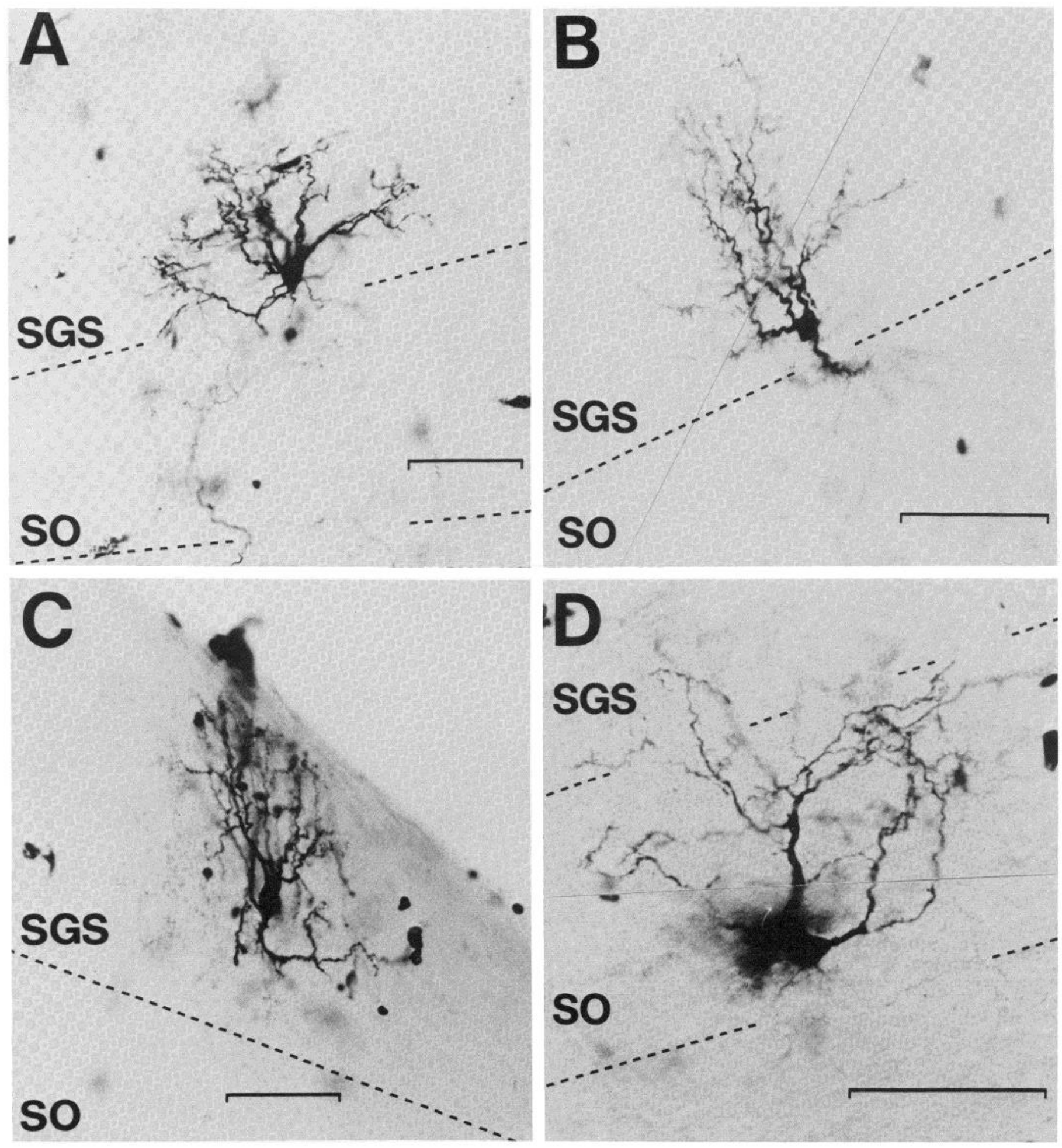

Figure 9. Photomicrographs of four additional narrow field vertical cells. These are reconstructed in Figure 10 . The calibrations are all $50 \mu \mathrm{m}$ and the conventions are the same as those in Figure 2.

oriented dendritic trees: narrow field vertical cells, wide field vertical cells, and pyriform cells. In the rat, some pyriform cells (see Langer and Lund, 1974, Fig. 11, and Labriola and Laemle, 1977, Fig. 4) have dendritic trees which are as restricted as those of narrow field vertical cells, and others have arbors which extend well into the range we (perhaps somewhat arbitrarily) defined for wide field vertical cells. In Langer and Lund's (1974) material, the critical distinguishing characteristic of pyriform cells appears to be the restriction of their somata to the border between the zone of horizontal cells and the zone of vertical cells (these divisions correspond closely to the upper and lower halves of the SGS).

In our admittedly limited sample, we were unable to define a subgroup of cells which were sufficiently distinctive to be classed as a separate group of pyriform neurons. One cell (Figs. 11 and 


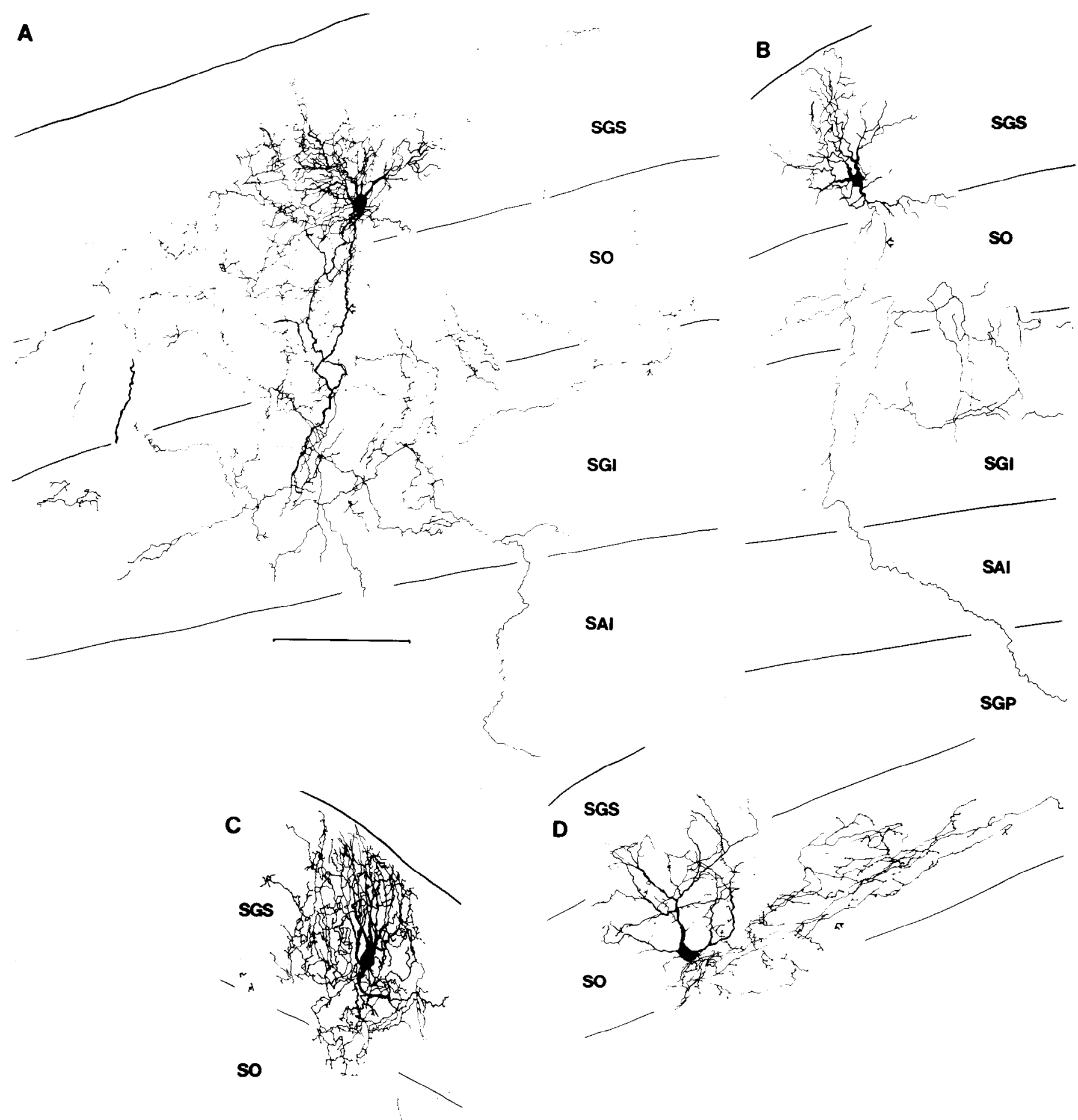

Figure 10. Reconstructions of the cells shown in Figure 9. The neuron in $A$ had its soma in the lower SGS and its dendritic arbor was restricted to this layer. Its axon ramified extensively in the lower SGS, SO, and SGl. One of its processes could be traced to stratum album intermedium (SAI). This cell was nondirectional, gave an on-off response to a flashed spot, and was discharged by stimulus velocities up to $200^{\circ} / \mathrm{sec}$. Its responses were reduced by stimult larger than the receptive field activing region. The cell in $B$ also had its soma in the lower SGS and an axon that ramified extensively in the lower SO and upper SGI. It was nondirectional, responded only to low speeds, and was unaffected by stimulus size. The cell in $C$ had a dendritic arbor similar to that shown in $B$, but its axonal collateralization was restricted to the region of the neuron's dendritic tree. The cell was unresponsive to flashed stimuli, nondirectional, had its responses suppressed by spots larger than the receptive field, and was discharged by stimulus velocities up to $250^{\circ} / \mathrm{sec}$. The cell in $D$ had its soma in the lower SO and its dendrites were restricted to this layer and the lower SGS. The axonal arborization of this cell was in the SO and was mostly medial to the cell. This neuron was nondirectional, responded only to low speeds and was unaffected by spot size. SGP, stratum griseum profundum.

12D) which we placed in the narrow field vertical class was fairly similar to a neuron which Langer and Lund (1974) characterized as pyriform (see their Fig. 11, left side). The soma of our HRP-filled cell was, however, located in the lower SO.
In comparing categories based upon Golgi and HRP material we should also note that the cells Tokunaga and Otani (1976) characterized as "widefield cylindrical neurons" (see their Fig. 5a) would have been classed as narrow field vertical cells in our study. They 

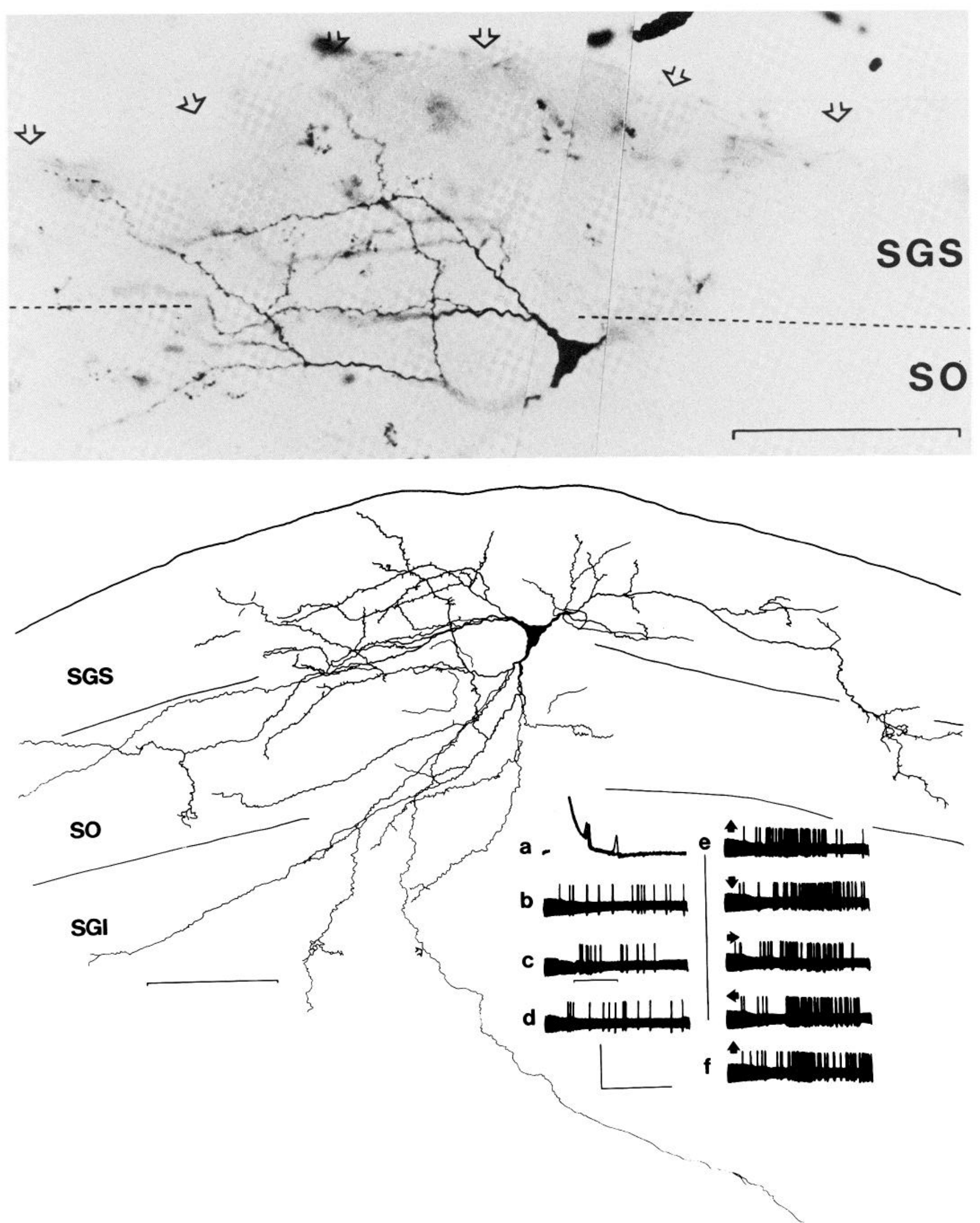

Figure 11. Photomicrograph, reconstruction, and oscilloscope traces depicting the responses of a cell with a widespread vertically oriented dendritic arbor. The soma of this neuron was located at the SGS-SO border and its dendrites were in the SGS and uppermost SO. The cell had an extensive axonal arborization in the SO and SGI. One axonal branch (open arrow in reconstruction) extended further into the deep laminae. The calibrations are $100 \mu \mathrm{m}$. The cell responded to thalamic shocks $(725 \mu \mathrm{A})$ with a latency of $2.8 \mathrm{msec}(\mathrm{a})$. It fired spontaneously at a variable rate which reached a maximum of $3 \mathrm{~Hz}(b$ and $d)$ and gave an on-off discharge to a flashed spot $(c)$. The neuron responded to all directions of stimulus movement $\left(e\right.$, receptive field size $=4.7^{\circ}$, spot size $=3^{\circ}$, stimulus speed $=15^{\circ} / \mathrm{sec}$; arrows denote stimulus direction). Its discharges were not attenuated by spots larger than the receptive field ( $f$, spot size $=15^{\circ}$, all else as in e). The calibrations are $10 \mathrm{mV}$ and $5 \mathrm{msec}$ for $a$ and $10 \mathrm{mV}$ and $2.5 \mathrm{sec}$ for $b$ to $f$. All recordings are extracellular. 

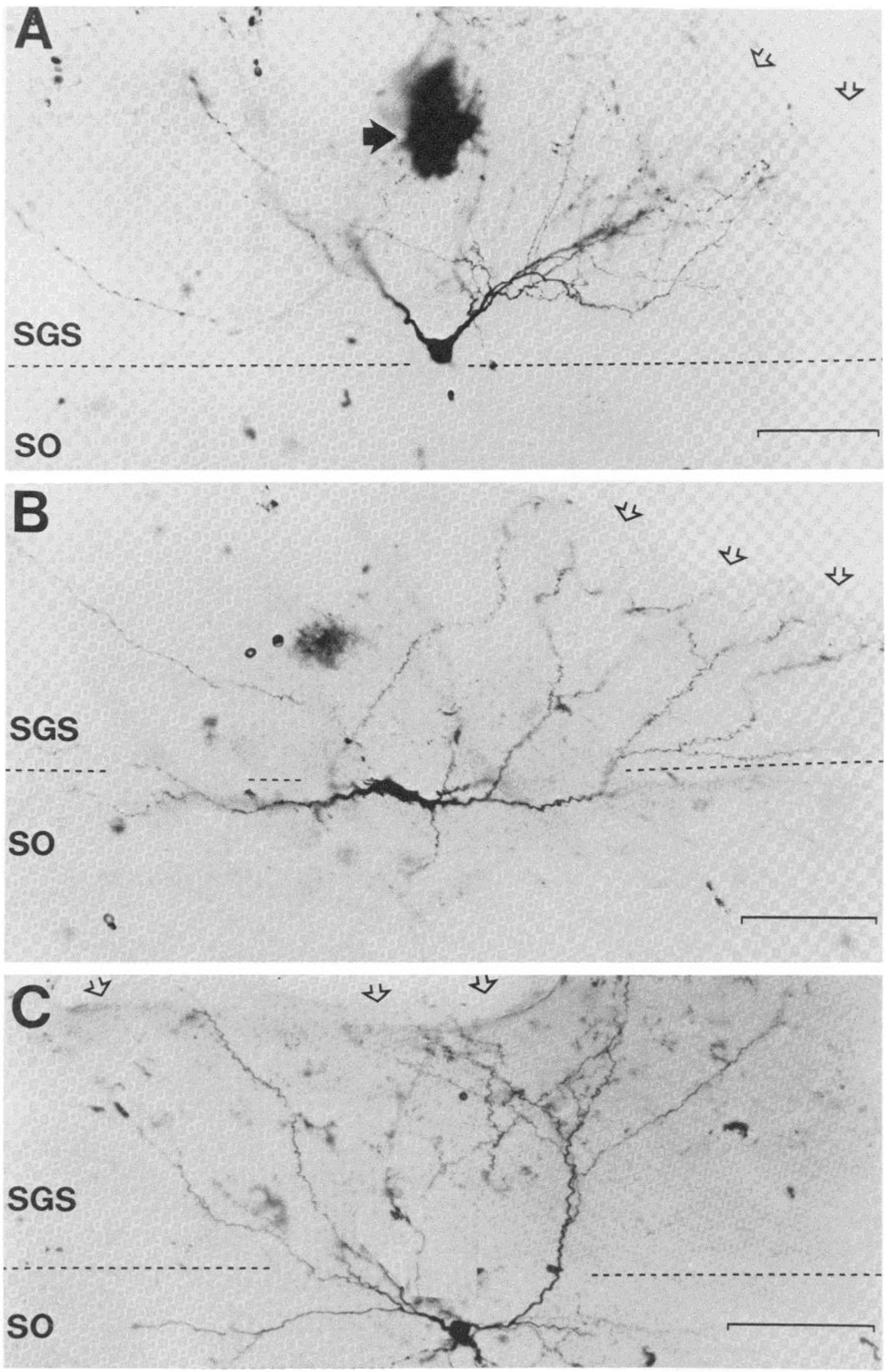

Figure 12. Photomicrographs of three additional wide field vertical cells. The solid arrow in $A$ points to a number of red blood cells slightly out of the plane of focus. The calibrations are all $50 \mu \mathrm{m}$. All other conventions are the same as in Figure 2. 

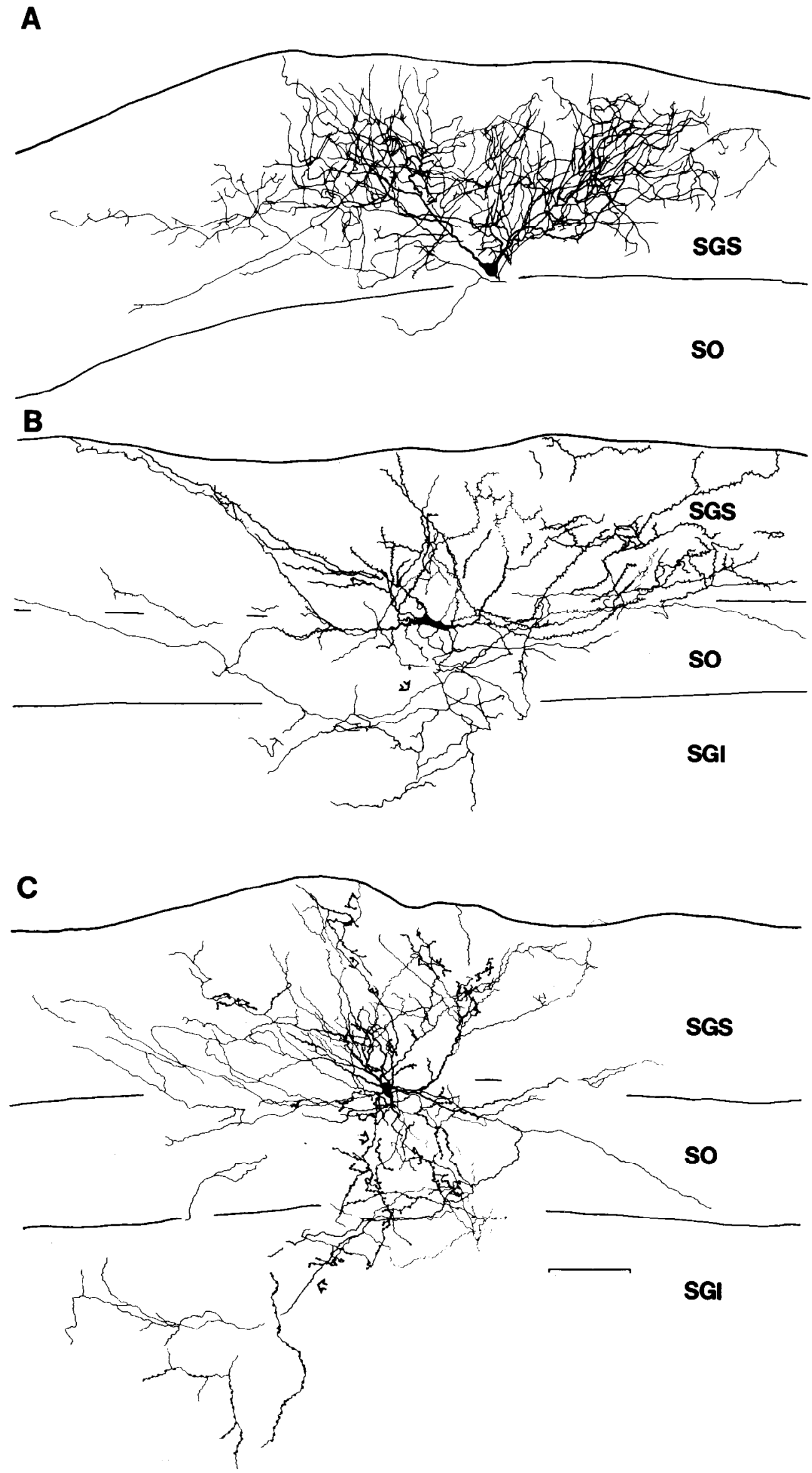

Figure 13. Reconstructions of the wide field vertical cells shown in Figure 12. All three of these neurons had their cell bodies at the SGS-SO border and dendritic arbors which extended into the SGS, reaching the pial surface. Only a single axonal branch of the cell shown in $A$ could be traced. It remained in the region of the neuron's dendritic arbor. The cells in $B$ and $C$ had extensive axonal arborizations in the SO and SGl. The cell in $A$ was nondirectional, gave an on-off response to a flashed spot, was discharged by stimulus speeds up to $100^{\circ} / \mathrm{sec}$, and its responses were suppressed by stimuli larger than the receptive field. The cell in $B$ was directionally selective, preferring upward stimulus movement. It gave an on-off response to flashed spots, was discharged by stimulus speeds in excess of $150 \% \mathrm{sec}$, and was unaffected by spot size. The cell in $C$ was unresponsive to flashed stimuli, nondirectional, responded only to low $(<10 \% \mathrm{sec})$ speeds, and had its discharges suppressed by spots which exceeded the size of the receptive field. The calibration for the reconstructions is $100 \mu \mathrm{m}$. 

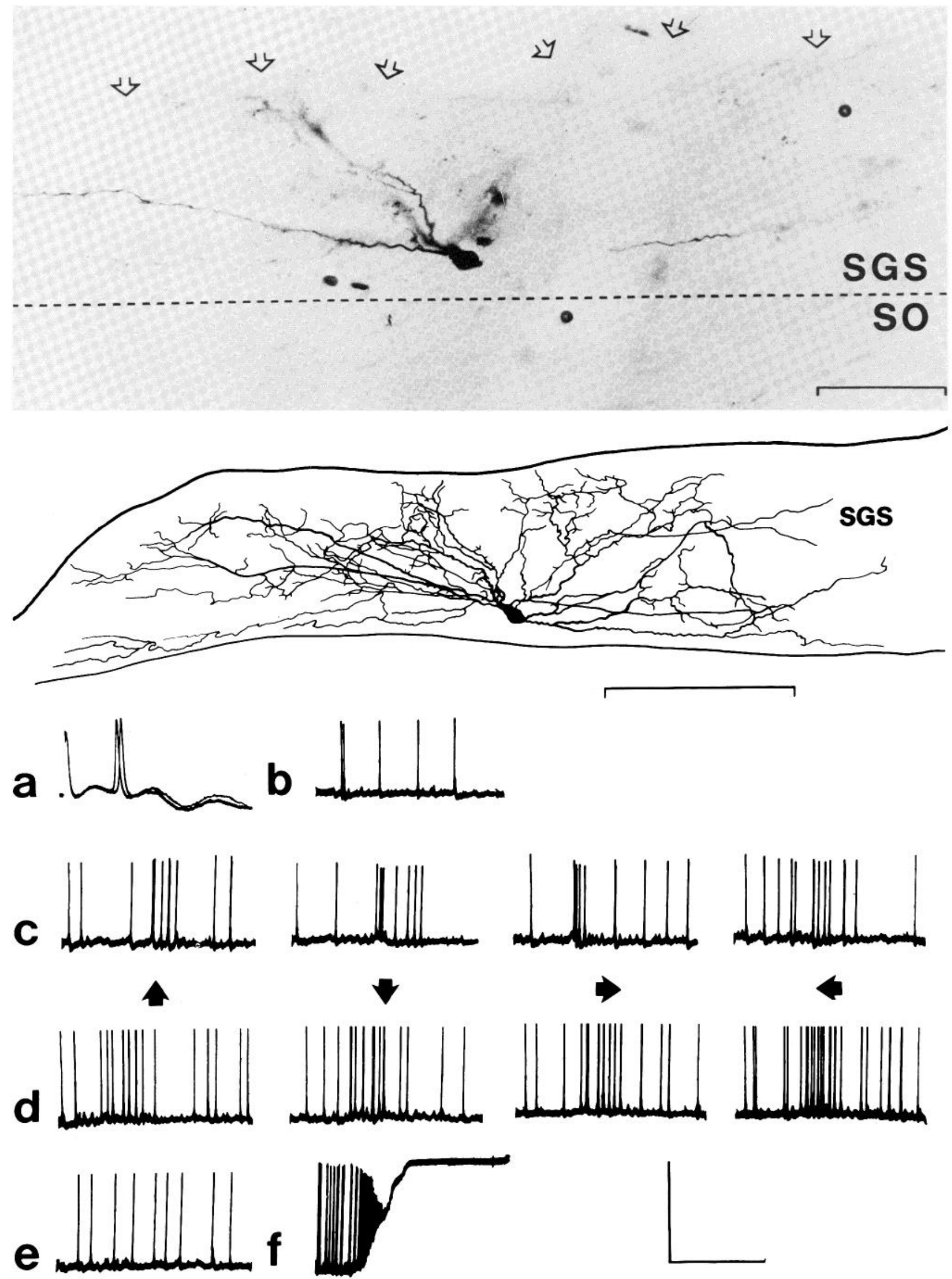

Figure 14. Photomicrograph, reconstruction, and oscilloscope traces illustrating the responses of a horizontal cell. The soma was located in the lowermost SGS and the cell's dendritic arborization was limited to this lamina. An axon could not be unequivocally identified for this neuron. The calibration for the photomicrograph is $100 \mu \mathrm{m}$; that for the reconstruction is $200 \mu \mathrm{m}$. a (two overlapped oscilloscope traces) illustrates the cell's response to thalamic shocks $(130 \mu \mathrm{A})$ and $b$ shows the neuron's spontaneous activity. $c$ and $d$ depict responses to different directions of stimulus movement (receptive fields $=4 \times 8^{\circ}$, spot $=3^{\circ}$, stimulus speed $=25^{\circ} / \mathrm{sec}$; arrows indicate stimulus direction). Trace $e$ again illustrates the cell's spontaneous activity and $f$ shows the positivegoing DC shift when the electrode was removed from the cell. The traces in a to $c$ were taken prior to injection; those in $d$ to $f$ were taken after the injection was completed. The calibrations are $50 \mathrm{mV}$ and $10 \mathrm{msec}$ for a and $50 \mathrm{mV}$ and $1 \mathrm{sec}$ for all other traces. All recordings are intracellular. 


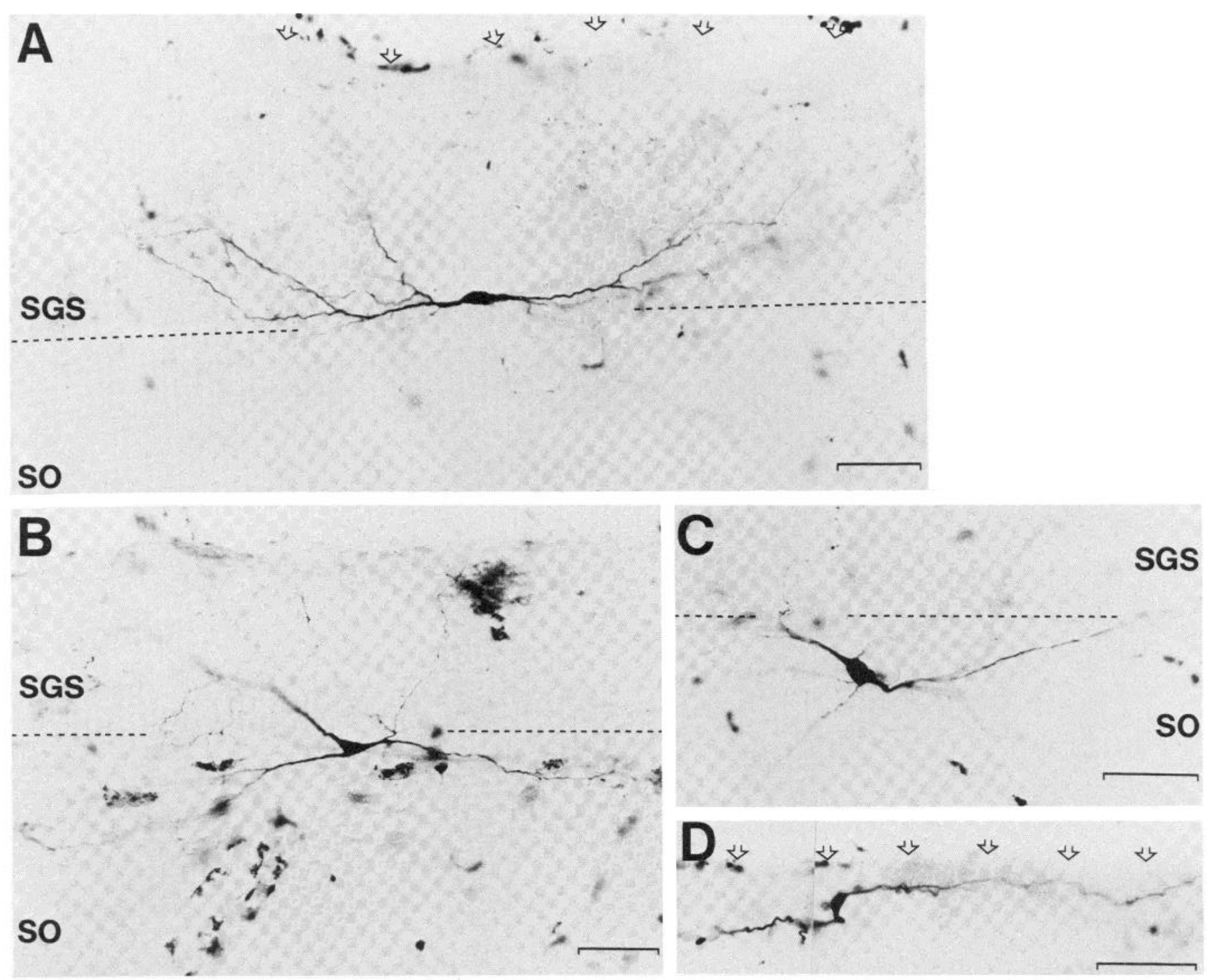

Figure 15. Photomicrographs of four additional horizontal cells which are reconstructed in Figure 16. The calibrations are all $50 \mu \mathrm{m}$. All other conventions are the same as in Figure 2.

also appear similar to the narrow field vertical cells of Langer and Lund (1974).

The preceding paragraphs point out one of the major difficulties involved in attempting to correlate neuronal structure and function: it is possible that some relationships between these two variables may be missed because morphological categories are too broadly defined. Nevertheless, our approach has been to group cells into categories that could be distinguished unequivocally.

Relationships to SC afferent organization. It is well known that the major visual inputs to the superficial SC laminae have a highly stratified organization (see Huerta and Harting, 1984, for a recent review), and it has been noted in several species that the responses of cells in different parts of the superficial laminae may reflect this afferent organization (e.g., Mcllwain and Fields, 1971; Hoffmann, 1973; Mcllwain and Lufkin, 1976; Albano et al., 1978; Fukuda and Iwama, 1978). In this discussion, we will consider only those inputs from the retina and striate cortex.

In the rodent, the results of several studies (e.g., Fukuda, 1977, Rhoades and Chalupa, 1979; Chalupa and Thompson, 1980; Linden and Perry, 1983) have indicated that all classes of retinal ganglion cells send axons to the SC. There is, however, evidence from both cats and rodents that the finer and more slowly conducting axons terminate most superficially, whereas larger caliber axons innervate the deeper parts of the SGS and SO (e.g., Mcllwain and Lufkin, 1976; Mcllwain, 1978; Bowling and Michael, 1980; Behan, 1981; Hofbauer and Dräger, 1981; Itoh et al., 1981; Mize, 1983; Sachs and Schneider, 1984). The relationship between these terminal zones and the locations of the neurons which receive contacts from a given type of retinal afferent are not, however, completely clear. Several investigators (e.g., Mcllwain and Fields, 1971; Hoffmann, 1973; Mcllwain and Lufkin, 1976; Fukuda et al., 1978) have reported that SC neurons innervated by rapidly conducting or $Y$-type retinal axons are almost invariably located in the lower SGS and SO. As might also be expected from the anatomical data, collicular cells receiving input from very slowly conducting retinal axons have also been recorded in the uppermost portion of the SGS (e.g., Fukuda et al., 1978). At the same time, however, Fukuda et al. (1978) and Ogawa and Takahashi (1981) have both reported that some neurons in the lower SGS receive input from slowly conducting or W-type retinal ganglion cells. In the latter study, procion yellow injections suggested that these neurons were wide field vertical cells. An additional experiment which employed current source density anal- 

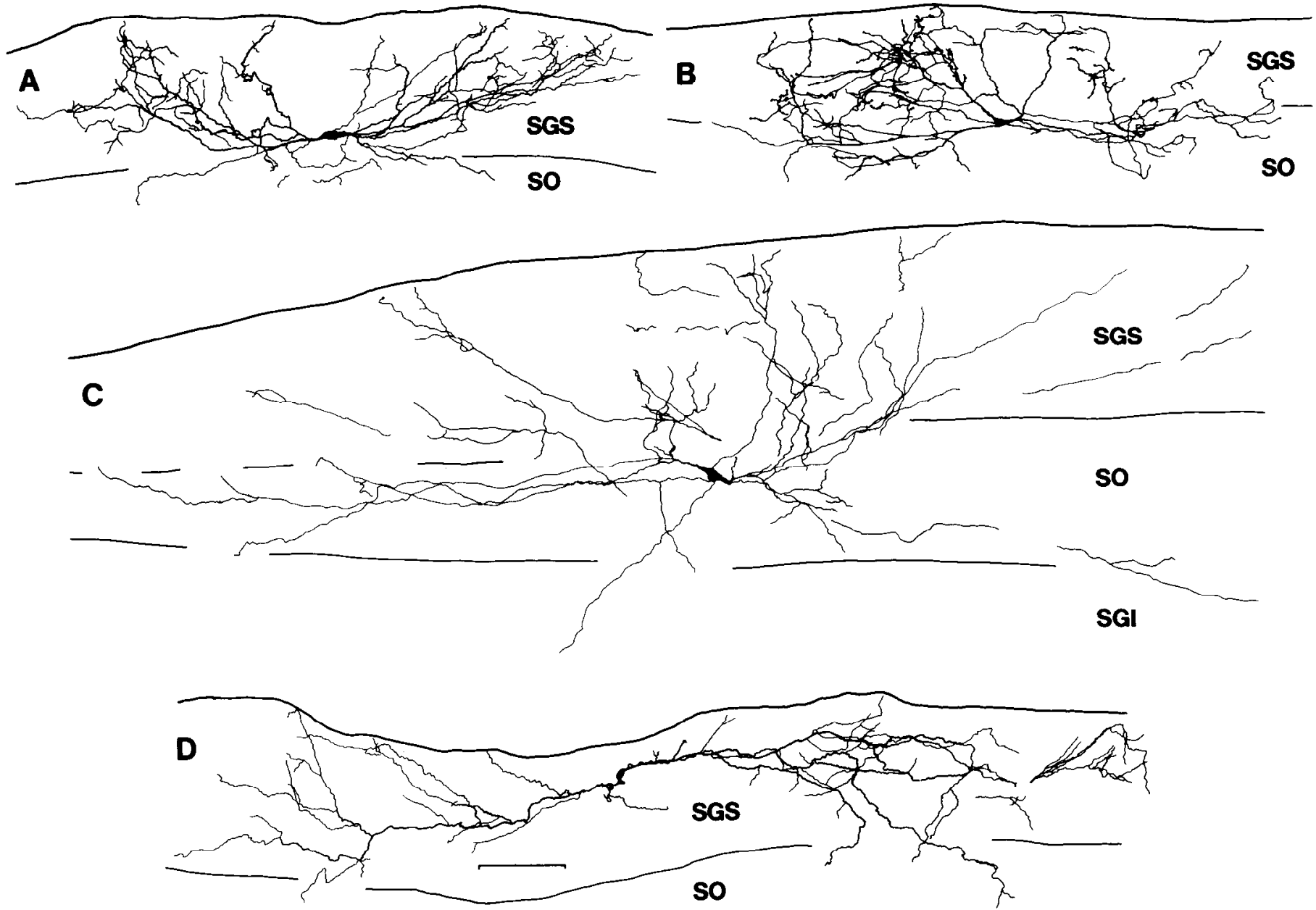

Figure 16. Reconstructions of the four horizontal cells depicted in Figure 15. The neurons in $A$ and $B$ had their cell bodies at the SGS-SO border and dendrites in the upper SO and SGS. No axon could be identified for the cell shown in $A$. The cell shown in $B$ gave off several axon collaterals in the SGS. Both cells were nondirectional, gave on-off responses to flashed stimuli, were unaffected by spot size, and responded to speeds in excess of $100^{\circ} / \mathrm{sec}$. The cell in $C$ had its soma in the SO and a dendritic span of more than $1400 \mu \mathrm{m}$. The axon of this cell could not be identified. This neuron did not respond to any of the sensory stimuli we employed. The neuron shown in $D$ had its soma in the upper SGS and an extensive dendritic arborization in the SGS. The axon of this cell could not be identified. This neuron was axially selective, gave an on response to a flashed spot, and responded only to speeds $<10^{\circ} / \mathrm{sec}$. This cell was unaffected by stimulus size. The calibration for the reconstructions is $100 \mu \mathrm{m}$.

ysis in guinea pig (Johnson and King, 1982) concluded that slowly conducting retinal axons terminated in the upper SGS and made synapses onto the dendrites of cells located in the lower part of this layer. Conversely, rapidly conducting axons were thought to terminate in the lower SGS and synapse onto the dendrites of cells located in the upper portion of this lamina.

One electrophysiological study in the rats (Fukuda and Iwama, 1978) has observed some weak correlations between neuronal response properties in colliculus and the conduction velocity of retinal afferent input. Such relationships have also been observed in the cat (e.g., Hoffmann, 1973). In hamsters, the only significant correlation between the conduction velocity of retinal afferents and SC receptive fields was with respect to direction selectivity. Rhoades and Chalupa (1979) reported that directionally selective neurons had a strong tendency to be driven by slowly conducting retinal axons. Those data fit well with our current finding that stellate and especially marginal cells were directionally selective more often than other morphological types. The proximal dendrites of directionally selective neurons in these classes were located in the upper SGS and thus were likely to receive contacts from slowly conducting retinal axons. Also of interest in this regard is the fact that only one of the five stellate cells located in the SO was directionally selective. Thus, all but three of the marginal and stellate cells recovered from the SGS were directionally selective.
Stellate and marginal cells, in most cases, also responded only to slowly moving stimuli which also might be predicted by the supposition that they receive input from slowly conducting retinal axons (see Stone and Fukuda, 1974, for a review of the receptive field properties of W-type retinal ganglion cells). In this regard, however, it must be noted that Rhoades and Chalupa (1979) observed no corrclation between speed selectivity and conduction velocity of retinal input in their study.

The relationship between the terminal distribution of the striate corticocollicular projection and the morphology and receptive field properties of SC neurons is much less clear than that discussed above for the retinocollicular pathway. It is well known that the striate cortical input to the superficial layers is necessary for the synthesis of receptive fields of most directionally selective SC neurons in the hamster (Chalupa and Rhoades, 1977) and the cat (Wickelgren and Sterling, 1969; Rosenquist and Palmer, 1971; Stein and Arigbede, 1972; Stein et al., 1975; Mize and Murphy, 1976; Stein, 1977)

In hamsters, this projection innervates the lower half of the SGS and the upper SO (e.g., Rhoades 1981; Rhoades and Fish, 1983). This region is, of course, ventral to the proximal dendrites of the directionally selective marginal cells. The ventrally directed dendrites of directionally selective SGS stellate neurons do, however, extend into the striate corticorecipient zone of the tectum. Yet, previous extracellular recording studies (Rhoades and Chalupa, 1978) have 

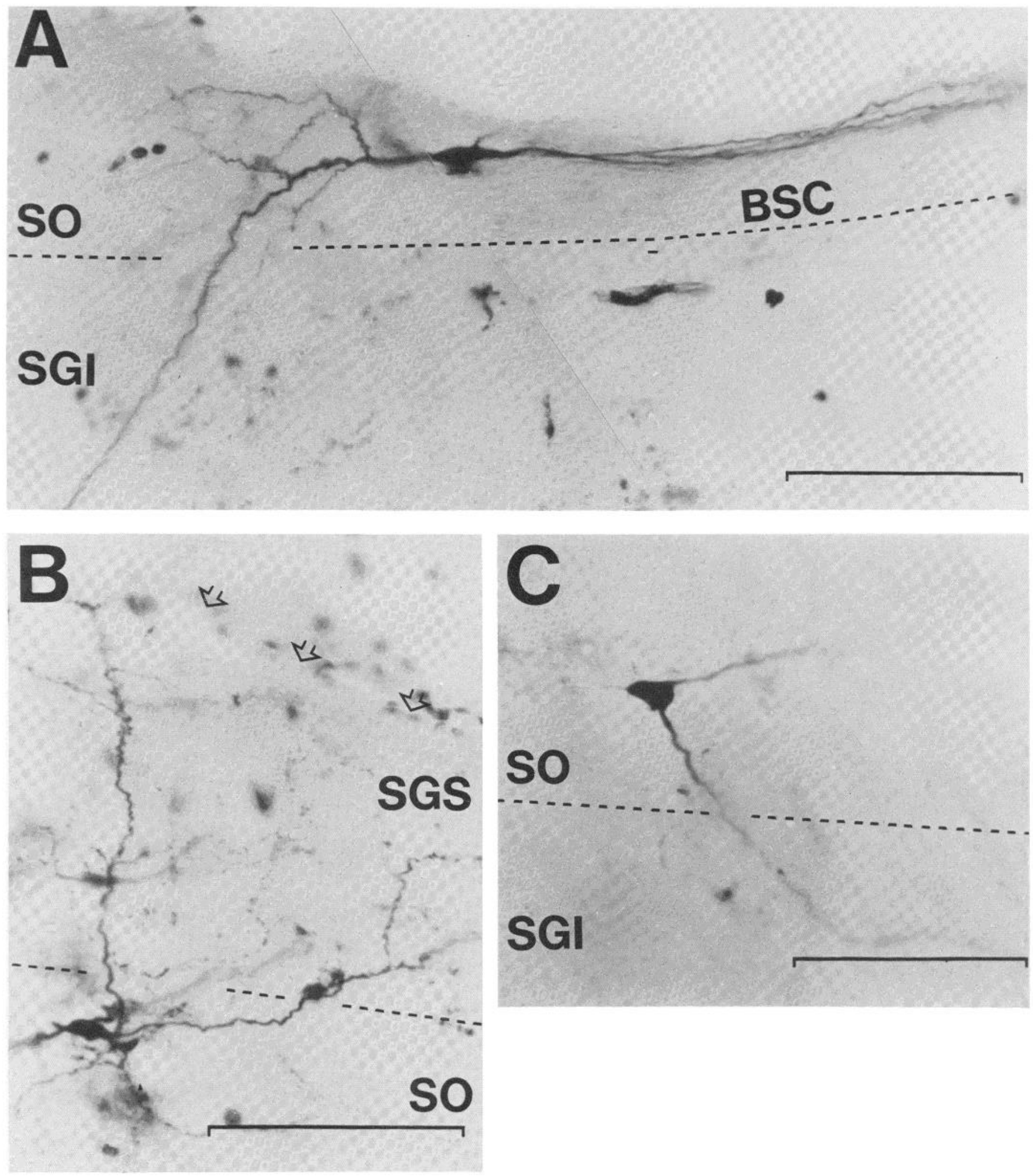

Figure 17. Photomicrographs of three cells which could not be placed in the five categories used in this study. The calibrations are all $100 \mu \mathrm{m}$. BSC, brachium of the superior colliculus. All other conventions are the same as in Figure 2.

shown that the vast majority of the cells recorded in the upper SGS of the hamster's SC are not activated by striate cortical shocks (see especially their Fig. 7). Thus, although the striate corticotectal pathway is clearly necessary for the organization of directionally selective SC neurons, our experiments shed relatively little light on the manner in which such receptive fields are synthesized.
Conclusions. The results of this study show that the receptive field properties and morphology of SC neurons can be related, but that these relationships are by no means invariant. Each morphologically defined class exhibited at least some variability in their response properties. The marginal cells were most homogeneous functionally, and this may reflect the relatively limited distribution of 


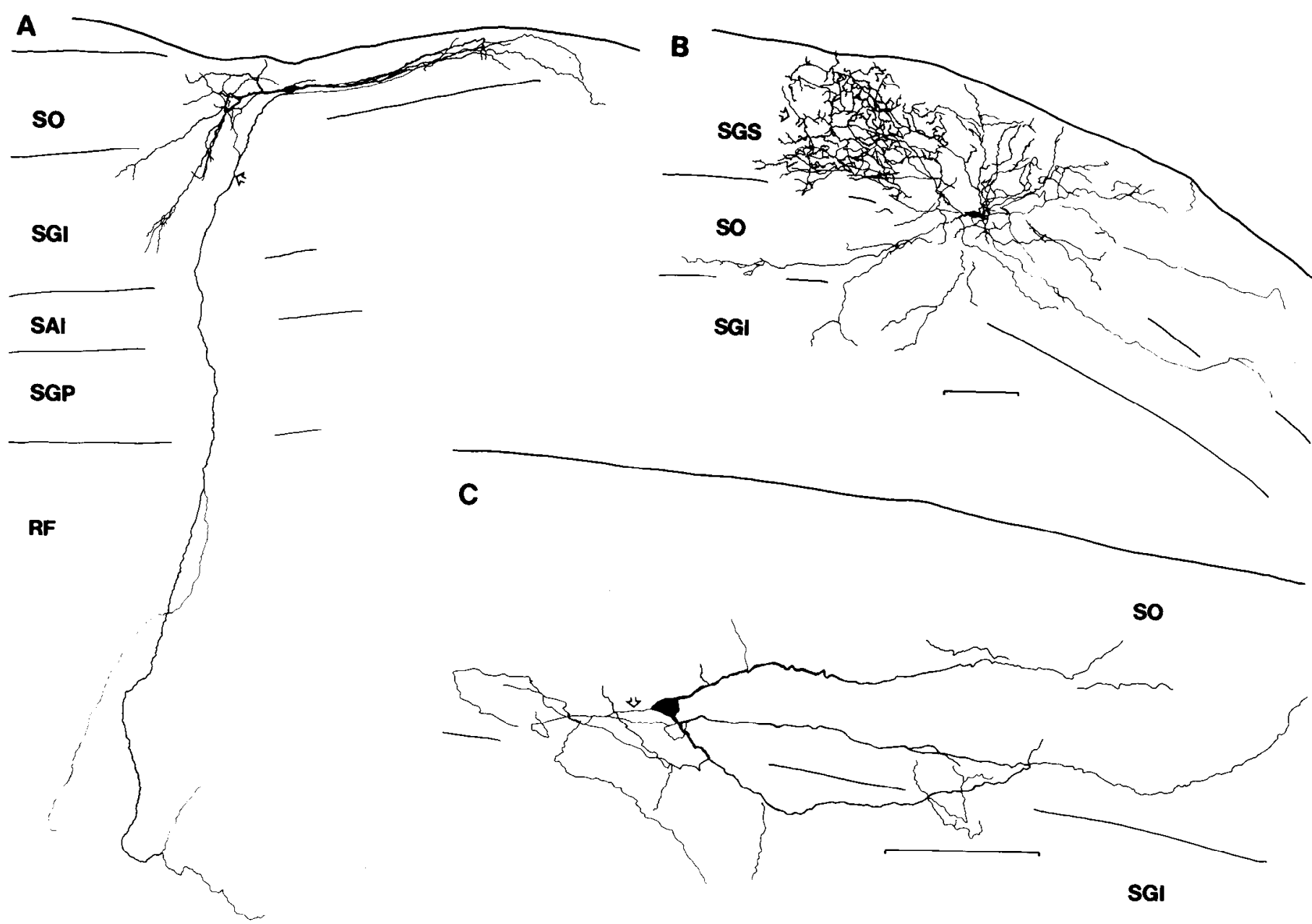

Figure 18. Reconstructions of the neurons shown in Figure 17. The cell in $A$ had its soma in the most lateral part of the SO, and its dendrites extended laterally into the brachium of the superior colliculus $(B S C)$ and medially into the $S O$ and SGl. Its axon (arrow) descended into the mesencephralic reticular formation $(R F)$. This cell was somatosensory and responded only to deflection of the mystacial vibrissae. SAl, stratum album intermedium; SGP, stratum griseum profundum. The cell in $B$ had its soma at the SGS-SO border and dendrites in the SGS, SO, and SGI. It had a dense axonal collateralization (arrow) medial to the soma in the SGS. This neuron was unresponsive. The cell in C had its soma in the lower SO and dendrites which extended laterally in the SO and upper SGI. Its axon (arrow) collateralized medial to the soma in the lower SO and upper SGI. This cell was nondirectional, responded to speeds up to $50^{\circ} / \mathrm{sec}$, and was not discharged by flashed stimuli. Effects of stimulus size were not tested for this cell. The calibrations are all $100 \mu \mathrm{m}$. That in $B$ also applies to $A$.

their dendritic arbors. The narrow and wide field vertical cells were functionally more variable. Two of the latter group were excited only by somatosensory stimulation. The functional heterogeneity of these cells may reflect the greater tangential and laminar extents of their dendritic trees.

\section{References}

Adams, J. C. (1977) Technical considerations on the use of horseradish peroxidase as a neuronal marker. Neuroscience 2: 141-145.

Albano, J. E., A. L. Humphrey, and T. T. Norton (1978) Laminar organization of receptive-field properties in tree shrew superior colliculus. J. Neurophysiol. 41 : 1140-1164.

Behan, M. (1981) Identification and distribution of retinocollicular terminals in the cat: An electron microscopic autoradiographic analysis. J. Comp. Neurol. 199: 1-15.

Bowling, D. B., and C. R. Michael (1980) Projection patterns of single physiologically characterized optic tract fibres in cat. Nature 286: 899902.

Chalupa, L. M. (1984) Visual physiology of the mammalian superior colliculus. In Comparative Neurology of the Optic Tectum, H. Vanegas, ed., pp. 775818, Plenum Publishing Corp., New York.

Chalupa, L. M., and R. W. Rhoades (1977) Repsonses of visual, somatosert- sory and auditory neurons in the golden hamster's superior colliculus. J. Physiol. (Lond.) 270: 595-626.

Chalupa, L. M., and R. W. Rhoades (1978) Modification of visual response properties in the superior colliculus of the golden hamster following stroboscopic rearing. J. Physiol. (Lond.) 274: 571-592.

Chalupa, L. M., and I. Thompson (1980) Retinal ganglion cell projections to the superior colliculus of the hamster demonstrated by the horseradish peroxidase technique. Neurosci. Lett. 19: 13-19.

Freminet, A., E. Bursaux and C. Poyart (1972) Mesure de la vitesse de renouvellement du lactate chez le rat par perfusion de ${ }^{14} \mathrm{C}-U$ - $(\mathrm{L})$-lactate ${ }^{+}$. Pflugers Arch. 334:293-302.

Fukuda, Y. (1977) A three group classification of rat retinal ganglion cells: Histological and physiological studies. Brain Res. 119: 327-344.

Fukuda, Y., and K. Iwama (1978) Visual receptive field properties of single cells in the rat superior colliculus. Jpn. J. Physiol. 28: 385-400.

Fukuda, Y., D. A. Suzuki, and K. Iwama (1978) A four group classification of the rat superior collicular cells responding to optic nerve stimulation. Jpn. J. Physiol. 28: 367-384.

Gallyas, F. (1979) Silver staining of myelin by means of physical development. Nourol. Ros. 1: 203209.

Grantyn, R., R. Ludwig, and W. Eberhardt (1984) Neurons of the superficial tectal gray. An intracellular HRP-study on the kitten superior colliculus in vilro. Exp. Brain Res. 55: 172-176. 
Hofbaucr, A., and U. Drägcr (1981) Depth segregation of retino-tectal projections in the mouse. Invest. Ophthalmol. Vis. Sci. 20: 175.

Hoffmann, K. P. (1973) Conduction velocity in pathways from retina to superior colliculus ir the cal: A correlation with receptive-field properties. J. Neurophysiol. 36: 409-424.

Huerta, M. F., and J. K. Harting (1984) The mammalian superior colliculus: Studies of its morphology and connections. In Comparative Neurology of the Optic Tectum, H. Vanegas, ed., pp. 687-773, Plenum Publishing Corp., New York.

Irvin, G. E., T. T. Norton, and T. K. Kuyk (1983) Morphology of physiologically identified neurons in the superior colliculus of the tree shrew. Invest Ophthalmol. Vis. Sci. 24: 224

Itoh, K., M. Conley, and I. T. Diamond (1981) Different distributions of large and small retinal ganglion cells in the cat after HRP injections of single layers of the lateral geniculate body and the superior colliculus. Brain Res. 207: $147-153$

Johnson, M. S., and A. J. King (1982) The synaptic organization of the optic input to the guinea-pig superior colliculus. J. Physiol. (Lond.) 334: 20-21 $P$

Labriola, A. R., and L. K. Laemle (1977) Cellular morphology in the visual layers of the developing rat superior colliculus. Exp. Neurol. 55: 247-268.

Langer, T. P., and R. D. Lund (1974) The upper layers of the superior colliculus of the rat: A Golgi study. J. Comp. Neurol. 158: 405-436.

Linden, R., and V. H. Perry (1983) Massive retinotectal projection in rats Brain Res. 272: 145-149.

Mathers, L. H. (1977) Postnatal maturation of neurons in the rabbit superior colliculus. J. Comp. Neurol. 173: 439-456.

Mcllwain, J. T. (1978) Cat superior colliculus: Extracellular potentials related to W-cell synaptic actions. J. Neurophysiol. 41 : 1343-1358.

Mcllwain, J. T., and H. L. Fields (1971) Interactions of cortical and retina projections on single neurons of the cat's superior colliculus. J. Neurophysiol. 34: 763-772.

Mcllwain, J. T., and R. B. Lufkin (1976) Distribution of direct Y-cell inputs to the cat's superior colliculus: Are there spatial gradients? Brain Res. 103 $133-138$.

Mize, R. R. (1983) Variations in the retinal synapses of the cat superior colliculus revealed using quantitative electron microscope autoradiography. Brain Res. 269: 211-221.

Mize, R., and E. H. Murphy (1976) Alterations in the receptive field properties of superior colliculus cells produced by visual cortex ablations in infant and adult cats. J. Comp. Neurol. 168: 393-424.

Mooney, R. D., S. E. Fish, and R. W. Rhoades (1984) Anatomical and functional organization of pathway from superior colliculus to lateral posterior nucleus in hamster. J. Neurophysiol. 51: 407-431.

Ogawa, T., and Y. Takahashi (1981) Retinotectal connectivities within the superficial layers of the cat's superior colliculus. Brain Rcs. 217: 1-11

Rhoades, R. W. (1981) Expansion of the ipsilateral visual corticotectal projection in hamsters subjected to partial lesions of the visual cortex during infancy: Anatomical experiments. J. Comp. Neurol. 197: 425-445.

Rhoades, R. W. (1980) Response suppression induced by afferent stimula tion in the superficial and deep layers of the hamster's superior colliculus. Exp. Brain Res. 40: 185-195.
Rhoades, R. W., and L. M. Chalupa (1977) Differential effects of stimulus size upon "on" and "off" responses of superior collicular neurons. Exp. Neurol. 57: $57-66$.

Rhoades, R. W., and L. M. Chalupa (1978) Functional and anatomical consequences of neonatal visual cortical damage in the superior colliculus of the golden hamster. J. Neurophysiol. 41: 1466-1494.

Rhoades, R. W., and L. M. Chalupa (1979) Conduction velocity distribution of the retinal input to the hamster's superior colliculus and a correlation with receptive field properties. J. Comp. Neurol. 184: 243-264.

Rhoades, R. W., and L. M. Chalupa (1980) Effects of neonatal enucleation on receptive-field properties of visual neurons in superior colliculus of the golden hamster. J Neurophysiol. 4.3: 595-611.

Rhoades, R. W., and S. E. Fish (1983) Bilateral enucleation alters visual callosal but not corticotectal or corticogeniculate projections in hamster. Exp. Brain Res. 51: 451-462.

Rosenquist, A. C., and L. A. Palmer (1971) Visual receptive field properties of cells of superior colliculus after cortical lesions in the cat. Exp. Neurol. 33. 629-652.

Sachs, G. M., and G. E. Schneider (1984) The morphology of optic tract axons arborizing in the superior colliculus of the hamster. J. Comp. Neurol. 230: $155-167$

Semba, K., P. Masarachia, S. Malamed, M. Jacquin, S. Harris, G. Yang, and M. D. Egger (1983) An electron microscopic study of primary afferent terminals from slowly adapting type I receptors in the cat. J. Comp. Neurol. 221: $466-481$

Stein, B. E. (1977) Nonequivalent visual, auditory, and somatic corticotectal influences in cat. J. Neurophysiol. 41: 55-64.

Stein, B. E., and M. O. Arigbede (1972) Unimodal and multimodal response properties of neurons in the cat's superior colliculus. Exp. Neurol. 36: 179. 196.

Stein, B. E., and J. Dixon (1979) Properties of superior colliculus neurons in the golden hamster. J. Comp. Neurol. 183: 269-284.

Stein, B. E., B. Magalhães-Castro, and L. Kruger (1975) Effects of neonatal cortical lesions upon the cat superior colliculus. Brain Res. 83: 480-485.

Sterling, P. (1971) Receptive fields and synaptic organization of the superficial gray layer of the cat superior colliculus. Vis. Res. Suppl. 3: 309-328.

Stone, J., and $Y$. Fukuda (1974) Properties of cat retinal ganglion cells: Comparison of W-cells with $X$ - and $Y$-cells. J. Neurophysiol. 37: 722-748.

Takahashi, Y., and T. Ogawa (1978) Electrophysiological properties of morphologically identified neurons in the rabbit's superior colliculus. Exp. Neurol. 60: 254-266.

Takahashi, Y., T. Ogawa, T. Takimori, and H. Kato (1977) Intracellular studies of rabbit's superior colliculus. Brain Res. 123: 170-175.

Tokunaga, A., and K. Otani (1976) Dendritic patterns of neurons in the rat superior colliculus. Exp. Neurol. 52: 189-205.

Valverde, F. (1973) The neuropil in superíicial layers of the superior colliculus of the mouse. A correlated Golgi and electron microscopic study. Z. Anat. Entwicklungsgesch. 142: 117-147.

Wickelgren, B. G., and P. Sterling (1969) Influence of visual cortex on receptive fields in the superior colliculus of the cat. J. Neurophysiol. 32 : $16-24$. 